\title{
CENSERS AND INCENSE OF MEXICO AND CENTRAL AMERICA
}

\author{
BY
}

\section{WALTER HOUGH}

Curator of Ethnology, United States National Museum

No. 1887.-From the Proceedings of the United States National Museum, Vol. 42, pages 109-137, with Plates 3-14

Published April 17, 1912

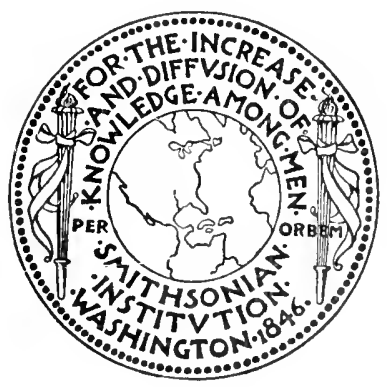

Washington

Government Printing ()ffice 



\title{
CENSERS AND INCENSE OF MEXICO AND CENTRAL AMERICA
}

\author{
BY \\ WALTER HOUGH \\ Curator of Ethnology, United States National Museum
}

No. 1887.-From the Proceedings of the United States National Museum, Vol. 42, pages 109-137, with Plates 3-14

Published April 17, 1912

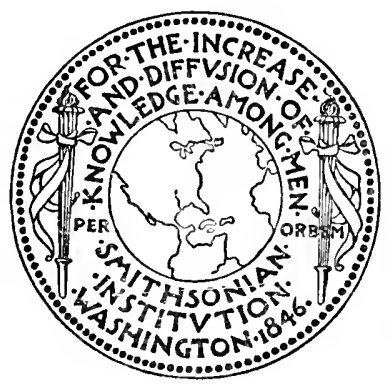

Washington

Government Printing Office 



\title{
CENSERS AND INCENSE OF MEXICO AND CENTRAL AMERICA.
}

\author{
By Walter Hough, \\ Curator of Ethnology, United States National Museum.
}

\section{INTRODUCTION.}

During the course of investigation on the utilization of fire the attention of the writer was drawn to several aboriginal American incense burners in the collection of the United States National Museum, and as these objects are rare and have never been discussed under one title, it was thought desirable to describe them, together with such American material as was procurable. Pére Lafitau remarks that "the altars of primitive times were not different from the ordinary house fire" and compares the portable altar or pyranon of the Greeks with the calumet of the Indians. ${ }^{1}$ The uncivilized tribes of America are still in the rudiments of the incense cult, their practices being confined mainly to oblations to fire, in the nature of individual acts or occasionally appearing as a single rite in ceremonies. For this reason the cult apparatus is very simple, like the pipe or analogous smoke-producing inventions, or the simple fireplace.

This paper therefore concerns itself with the apparatus foumd principally in Mexico and Central America, where several types occur, falling under the following classification, which also may be found applicable to the general subject.

\section{CLASSIFICATION OF CENSERS.}

I. Communal or General.

\section{STATIONARY.}

(a) Tribal, society, and family fireplaces, fire boxes, and fire altars.

Several idleas are involved in this division, such as preservation and renewal of fire for the health and well-being of the larger and smaller social units or religious organizations, as well as the beings themselves; sacrifice to fire by various oblations, with the idea of

1 Moeurs des sauvages americains, vol. 1, pp. 159 and 167, Paris, 1724. 
feeding, attracting, appeasing, or besceching the unseen beings. These and other unformulated acts associated with fire have been observed throughout the world among peoples of different degrees of culture.

(b) Great stone braziers, generally of hourglass shape, erected on masonry bases before temples or shrines. (Mexico.)

Stone basins borne by animal or human figures placed at shrines or sacred locations. (Chiapas, Yucatan, Mexico; Costa Rica; IIonduras; and Guatemala.)

Cireular stones on short pediments or caryatides; "altars" of shrines, in temples. (Yucatan and IIonduras.)

(c) Large pottery vessels of hourglass shape ornamented with masks, bands, knots, knobs, and spurs, and painted in colors. Placed as the stone braziers before temples or at shrines. Essentially Nahuatl. (Nahuatl Mexico; Guatemala; Costa Rica.)

II. Special.

\section{PORTABLE.}

(a) Braziers of small size used in dwellings. Of various forms. (Mexico.)

(b) Tripod censers consisting of a bowl mounted on three splayed feet preserving in general the hourglass form. Set on the ground. (Southern Mexico; Costa Rica.)

(c) Bowl censers, bearing a mask and other rudiments of human or animal forms, as in the monolithic braziers. (See I, b) (Cliapas and Yucatan, Mexico; Guatemala; Costa Rica.)

\section{GeSTURE CENSERS.}

(a) Flaring bowl with rudimentary handle and spurs representing other feet of tripod. (Oaxaca, Mexico.)

(b) Openwork pottery tripod vessel, one leg of which is extended to form a handle. Rattle feet. (Zapotec area, southern Mexico.)

(c) Spoon with truncated handle. Ventilation holes in bow. Rudle. (Zapotec area, southern Mexico.)

Small spoons with conventional animal handle. (Southern Mexieo; Costa Rica.)

(d) Ineruse larlle consisting of a bowl ventilated with openwork pattern and having a long, hollow handle containing rattles and torminating in a serpent or other head. Nahuatl form. (Contral Mexico.)

(o) 'Tubular pipes for incensing the esoterie beings and cardinal points. Pipes in general cult uses. (Ancient and modern Pucblos and other Indians, also northern Mexico and other Mexiean localities.)

(f) Cigarettes. (Mexico and ancient Pueblos.) 
3. SWINGING CENSERS.

(a) Censers introduced from Europe. Accultural. (Chiapas specimen.)

I. Communal or General.

\section{STATIONARY.}

(b) The great masonry brazicrs located before shrines about the teocallis, and at various other sacrificial spots where perpetual fires were maintained and offerings consumed were not strietly incense burners, though so treated at times. ${ }^{1}$ Usually upon them living victims were immolated and it was the custom to throw into the brazier fire the ashes and unconsumed incense from the portable censers together with the paraphernalia and offerings which had been employed in ceremonies. The brazier was the source from which live coals were taken to ignite the incense in the hand censers.

The brazier appears to be a perpetuation of the primitive communal fire, and the Nahuatl name by which such braziers were called, tlexictli, "fire navel," connotes an idea relating to birth and the underworld like the Hopi sipapu. In describing the ceremony of kindling new fire on the Hill of the Star in the valley of Mexico, Sahagun mentions the brazier: "The inhabitants of Mexico, having arrived home with their torches lighted, carried them at once to the temple of Uitzilopochtli and proceeded to place the fire, with much copal incense, on the great brazier of masonry elevated before the idol." 2 He also states that "they burned much night and day in the courts of the temples on the elevated fireplaces which they had made for that purpose." 3

Again he speaks (p. 101) of a round hearth set in the midst of the court where it was elevated two spans above the surface and to which celebrants carried for deposit the ashes and coals from the censers.

Another form of brazier, described briefly by Sahagun, was a stone basin encased in pine wood in which the flimsy ornaments and the mantas which had been worn by celebrants were burnt. Its name, quauxicalli, is interpreted "wood vase"; it was situated at the foot of the teocalli, while the great brazier in which vietims were burned stood on the apex platform.

There is in the United States National Museum a cylindrical block of hard eruptive rock having a rectangular shallow cavity 9 inches

\footnotetext{
$1 \mathrm{It}$ is said that there were 600 braziers of stone, some round and some square, about the great temple compound of Nexico. Bancroft, Native Rakes, vol. 2, p. 584, New York, 1875, eiting the Motolina 11 istoria de los Indios de la Nueva España in Icazbalceta, Col. cle Doc., vol. 1, p. 6i. (Since published by P'imental, Mexico, 1903.) Baneroft, Nalive Ralees, vol. 2, p. 56in, citing Veytia, Ilist. Antigua de Mejieo, vol. 3, p. 319, states that the streets of Mexico were lighted with braziers tended by the palrol.

2 Historia universal de la Neuva España, by Bernardino de Sahagun, translated by Jourdanet et Simeon. G. Missisoll, taris, 1880, p. 491.

Sahagun, work clted, p. 186.
} 
square cut in the upper surface which shows erosion as by fire, and it is thought that the specimen is a brazice such as Sahagun describes. A glyph resembling a conch shell is repeated around the periphery, between the upper and lower bordering bands, which are decorated with a textile design representing a braided band. The brazier is from Mexico and was collected by W. IV. Blake. Diame-
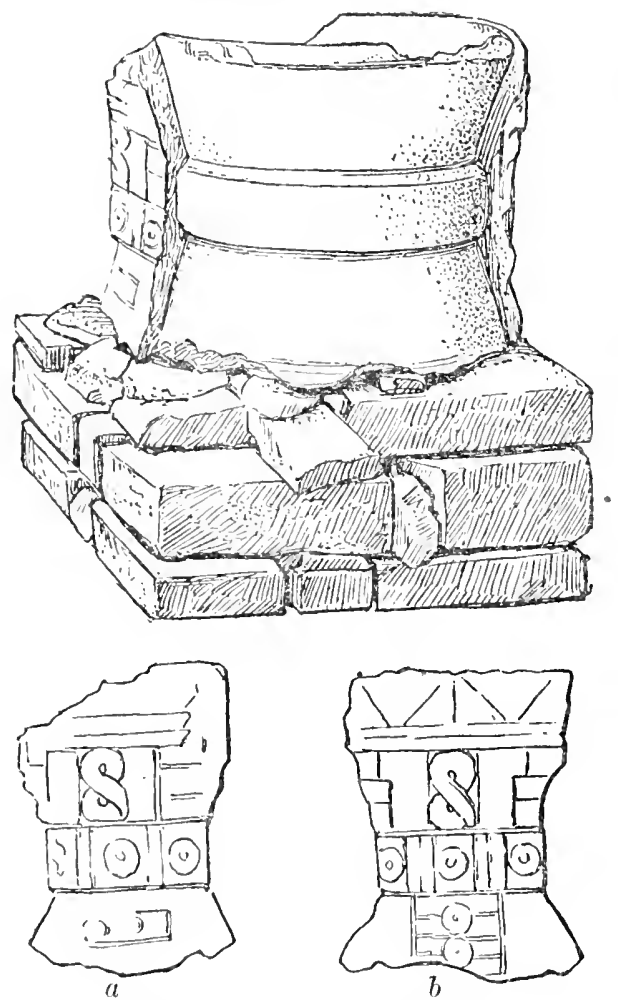

Fiff. 1-MONGLITHIC Brazier, TEOTIIUICAN. (a) AND (b), JESITNS ON SCUIITURED KNOTS.

ter, $15 \frac{1}{2}$ inches; height, 10 inches. (Acc. 17619, Orig. No. 126.) (Pl. 3 a. $)$

A perfect example of the ancient stone brazier (fig. 1) was brought to light a few years ago during the excarations by the Mexican Govermment at Teotihuacan. ${ }^{1}$ It was found on the upper horizontal plane of the central three-story temple at the base of the great Pyramid of the Sun and eonsists of a monolithic sculpture of hourglass shape set on a base of three courses of squared stone. With it were found two seulptured tablets and two dados. The brazier bears around the middle a band terminating on opposite sides in a complicated knot which hangs down to the base, the lappets below the tie corresponding to the four ends of the band. The knots bear signs consisting of disks, har's, and a figure 8 , like the twisted bread oflering mate to ("inapipittin," the signs diflering slightly on the two knots. (Fir. 1, a, b.) The tahkets and dados are stated to bear a like strmbelism. The form of the brazier described appears to be quite constant in the Vahuatl area and was carried wherever that influcnee went. The conception would seem to be that of the human form, which is more apparent in the pottery vessels of this class, to be noted latere ofiering more latitude to the seulptor than hard stone.

A sprecimen in form of an houreglass, of ereenstone, having a band of cords aromet the midklle and animal heads projecting on opposite 
sides has the appearance of the Nahuati type of brazier and may be assigned to that class. It comes from Costa Rica and was collected by C. N. Riotte in 1866. Diameter, $10 \frac{1}{2}$ inches; height, 11 inches. (Cat. No. 2347, U.S.N.M.) (Fig. 2.)

The stone basins borne by human or animal figures are mainly of the brazier class and represent this form among non-Nahuatl peoples. They are generally found south of the Nahuatl area and extend to Ecuador. The best known figures of this class are the specimen from Santa Lueia, Cozumalhuapa, Guatemala (pl. 3 b), in the Royal Museum of Berlin (see Catalogue Guide for 1904; Georg Reimer, Berlin), and the stone basin near Cuernavaca, Mexico.

A large monolithic sculpture in basalt representing two clasped human beings, the recumbent figure bearing a basin of ovate outline over the belly, exists in the United States National Museum. It is of heavy black basalt and comes from Costa Rica. (Pl. $3 c^{1}{ }^{1}$ ) The relation of this sculpture to several recumbent figures found in Mexico, the most celebrated being known as Chac-Mool, and others questionably spoken of as pulque gods, is quite close, and taken in connection with the fire navel idea (p. 111), the making of new fire on the belly of a victim, and the beliefs concerning fire, generation, and life, presents an interesting suggestion. In some cases basins held in the hands of stone figures have evidently been used for the burning of

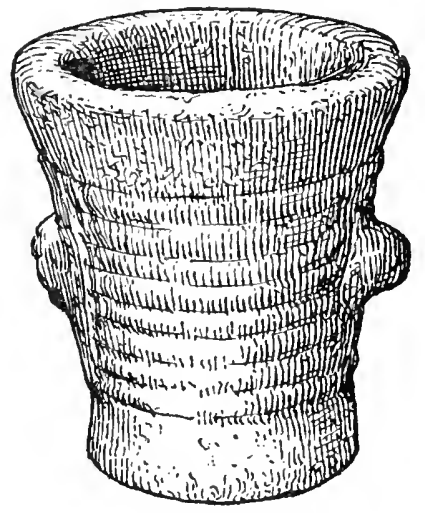

Fig, 2,-Brazier of HOURGLASS Form, Costa Rica. Collected by C. N. RIOTTE.

incense. In one of these specimens, about 3 feet high, found at Copan, Honduras, the basin is held up on a level with the chin of the idol. (Pl. 4.) This form appears to be related developmentally to the pottery bowl with the head on one side; it is discussed by Dr. Eduard Seler in Bulletin 2S, Bureau of American Ethnology, Washington, 1904, pages S4-85.

Dupaix figures an image of granite 12 inches in height representing a seated man with erossed legs and arms from Zachila, 10 to 12 miles south of Oaxaca. 'The sash about the loins of this figure has the knot at the back. Another from this locality has a hollow in the top of

\footnotetext{
1 Brazier. Basaltie roek, sculptured in the form of two clasped figures, the recumbent one beiring a basin held in the hands. The breasts hang over the elge of the basin. The head of this figure has been broken away, and the whole surface of the object is much worn by weather. It measures 33 inches long, 16 inches high, and 19 inches wirle at the greatest projections. Costa Rica. Collector unknown. (Calt. No. 179120 , U.S.N.M.)
}

$20441^{\circ}$ - Proc.N.M.vol.42-12-12-8 
the head and secms, like many others from this region, to be a rase or torch bearer. ${ }^{1}$

At Teotihuacan braziers were reeently found representing a human figure bending forward with hands on the ground and bearing a basin on the back. The specimen shown is in the Museo Nacional de México. The material is andesite, of light color. (Pl. 4.)

The George G. Heye expedition has recently discovered in Ecuador an old form of monolithic censer consisting of a seated figure with hands raised bearing a bowl in which there still remains half-burned incense.

The "sacrificial stone" of Mexico, which has a cavity in the middle from which leads a gutter passing over the flat surface and down the side, obviously worked out since the completion of the relief decoration, appears to have had a secondary use as a brazier. The function of the trough would be to facilitate drawing out the ashes, which, as Sahagun states, were carefully preserved for deposit in a place set apart for the purpose, and it is obvious that the thorough removal of every particle of the ashes could not well be accomplisher over the rough, sculptured surface of the stone. The following references to Sahagum describe the care with which ashes were preserved:

When they had finished the incensing they went to deposit the ashes in a round hearth ealled tlexictli (fire navel), which was placed in the midst of the court where it was elevated two spans above the surface. ${ }^{2}$

This having been done, the ashes and the objects which had bern amployed in the service of the gods were carried to the oratories called ayauhcalco (in the house of fogs or vapors).

(These oratories, also called ayauhcalli, were ordinarily placed on the banks of water courses. ${ }^{3}$ )

When the aurora appleared and when one could see the morning star they interred the athey belonging to the offering, likewise the flowers, the reeds where they burnt the perfumes, in the belief that these objects should not be seen by anyone ardicted to vices as would be ab man living in concubinage, an adulterer, a gambler or a drunkard; for they held all that kind as blemished and they forbid that they should see the interring of the ashes of the sacrifice. After they had put them in the ground, they began to sing and dance to the sound of the tambour and the teponazlli. ${ }^{4}$

1 number of altars have been discovered in Mexico and Central Americia, esperially by the field parties sent out by the Peabody Muscum. These are apparently not fire altars or censers, but the altar blexk of Stela $M$ in the hieroglyphie stairway of Copan ${ }^{5}$ in(o)poratert a lignre (smake) as in the animal and mask vases like those of the Lancandones, for example, figured log Maler and repro-

${ }^{1}$ Dupaix in Kingsborough, Mexican Antiquities, vol. 4, pl. 43.

Sahagun, work cited. p. ro\}.

'Translator's note, Sahagun, work citen], p. 74.

- Sahagun, work cited, p. 570.

- Mrm. Peaboty Mus, rol. I, No. 6, wh. 16.

' ldem, vol. 2, No. 1, p. 2s. 
duced in Tozzer's report. Stephens also found a copal altar in a room in the ruins of Tuloom, east coast of Yucatan. ${ }^{1}$

(c) Another class of stationary braziers are the large pottery vases of hourglass form which have been found in greater number in and about the City of Mexico than elsewhere. On account of their size and decoration, they are remarkable examples of the potter's art, while their form and decorative treatment seem to connect them closely with the genius of Nahuatl culture, whose spread by conquest has carried them far into Central America. This form may be regarded as the most characteristic of the middle American censer-braziers. Though not definitely mentioned by the early chroniclers, who speak usually of stone braziers when the material is given, they were surely in use in Mexico at the time of the conquest, those in the Museo Nacional de México, ${ }^{2}$ being the only form of brazier which has been recovered from the ruins of the ancient city.

One of the most striking exhibits of the great National Museum of Mexico are the enormous pottery vases, two of which were found in the ruins of the temple of the curato at Ixtapalapa, where was celebrated the cyclical feast of the kindling of the new fire, and one from Santiago Tlalteloleo. The vases each bears a human figure in high relief painted in colors, the face framed in the gaping mouth of a monster, suggesting a mask.

The specimen (pl. 5a) from Ixtapalapa has an hourglass body, lecorated with the figure of the god of fire (?), whose face appears somewhat in side view, who wears a girdle of human hands, has a circular sign like that of Chac-Mool (gorget?) in his middle, side loops or knots, and skirt hanging down slantingly on either side. The upper rim of the vase is decorated with hanging spikes. Another specimen from the same locality is similar to the one just described, but the legs and feet of the figure (pl. $5 b$ ) are better preserved. The third specimen, from Tlalteloleo, is almost denuded, griving one a view of the form of the vase. (Pl.5c.) A magnificent example, locality unknown, of rather slender form and in excellent preservation, shows excellently the conventionalized human figure wearing a crownlike headlless and with expanded wings springing from the sides of the body. (Pl. 6b.) The cinerary vase from Thaltololeo (pl. 6a) suggests in form the pottery brazier shown in plate $5 c$ and is a remarkable specimen in moleling and color. This vase was described by Brantz Mayer, ${ }^{3}$ who says that it is 22 incles high, $15 \frac{1}{2}$ inches in diameter, and that when found it had a lid and was filled with human skulls.

1 Yueatan, vol. 2, pp. 257-409.

1 Catálogo de Departamento de Arqueologiá del Museo Nacional. Jesus Galindo y Villa. IIéxico, 18ya.

a Afexico, vol. 2,1853, p. 274. 
These great pottery braziers are monuments to the modeler's skill in producing a foreeful work from crude material, and the final painting raises these objects immediately to a ligh plane of esthetic quality.

Dr. Eduard Seler, ${ }^{1}$ in his account of the finds in the calle de las Escalerillas, City of Mexico, some years ago, remarks:

About 20 meters to the east of the first skull altar, or, as we now know, the first Tezcatlipoca stone seat, were found two pottery vases three-quarters of a meter in height, presumably fire vases. They have on the lower border a decoration of knobs, and in the middle a band which in iront is bound into a large loop. A rather large hole is formed in the walls of the vase from side to side at the level of the band, possibly for the passage of a pole by means of which the heavy vesel was transported. (Pl. $7 a, b$.

It will be interesting to determine conelusively whether these braziers were transported by means of a pole, as suggested by the eurious

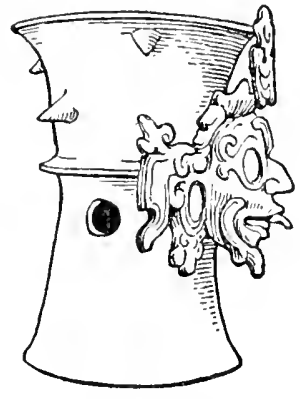

FIG, 3.-BRAZIER OF POTTERY, COPAN, HONDURAS. orifice passing through the body of the vase. If this opening is not comnected with the ventilation of the fire, the brazier probably was used in some rite which required its transportation from one place to another not far distant. The two Ixtapalapa braziers show this feature, but apparently the looles are too far off the center to admit of balance on a pole. (Pl.5a,b.) The Thalteloleo specinen (pl.5c) appears to have no such construction. The brazier figured by Dr. Seler 2 from ('opan, Honduras, is perforated in a similar manner. (Fig. 3.)

In deseribing a great censer urn from the cave of Quen SantoChacula, district of Nenton, Department of I Fueluetenango, Guatemala, Dr. Seler records that "in the depths of me of these caverns we found a kind of altar and walls which formed a chapel. We also found the idols in plare and large urns, the openwork walls of which represent the features of a demon having large eyes, colmiires springing from the mouth, and the nose and chin bristling with spines. One can imagine the effect this visage of the devil would produce when it was illuminated by the fire on the interior of the urn."3 (Fig. 4.)

Fnougl examples of the hourerlass-shape renser-brazicrs have been recovered to enable one to trace in their form and embellishment certain motives which remain in the conventionalized specimens found at the three-story temple at the base of the Pyramid of the Sun at Teotihuaean, those of the Calle de las Escalerillas in the (ity of

'Seler, Ges. Abh. zur Amer. Sprach u. Alterthumskunde, vol. 2, Berlin, 1904, p. 883.

2 Idem, vol. 3, p. 6r9.

Idem, vol. 2, p. 225. 
Mexico, and those showing more realism and complexity of ornament from Tlaltelolco.

It appears that in many cases masks, heads, or other members of animate beings as so-called decorative elements are really vestigial and refer back to vessels of realistic animal form, but ideas of such forms may be taken by the artist at any phase of design mutation from models to mere traces, and even to surface painting, which itself may undergo both progressive and retrogressive fluctuations at different periods. There is difficulty in placing the original forms and building the series. Thus the hourglass-shape brazier appears from vestiges to have been an animal form, probably human, and could have arizen from the erouched figure with bowl on back, examples of which have been found in various localities, or readily from the human being in seated pose. (Pl. S a.) Many archeological forms refer back to the human motive, as the seulptured ax and the small jade and other stones tablets of Mexico and Central America, whose meaning is made clear by the aid of certain decorative vestiges which they preserve. The most noticeable vestige on the hourglass brazier is the sash, seen on the Copan and Santa Lucia Cozumalhuapa specimens (pl. 4 and pl. 8 a), and conventionalized in the Teotihuacan and Escalerillas braziers, but with pendants of corn and fruits on the Tlalteloleo specimens. The elaborate knots and the lappets are very characteristic and are made to bear symbolie meaning, in this respect resembling the expressive knot systems of Japan, and perhaps the evineseent cord figures of various peoples. The same idea obtains

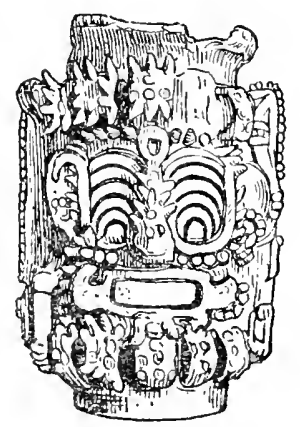

Fig. 4.-Brazier or CENSEr URN, GUATEMaLA. in the Pueblo region of the southwestern United States, where sacred incense cigarettes of reed joints are bound with cotton cords, the ends hanging free and the knot or other portion of the cord frecquently securing shell beads of discoidal or pendent form. (See fig. $10 a-e$.) Sometimes a small woven cotton sasli is secured around the eane joint. In the same category are the pallos of the Pueblos, ${ }^{1}$ which represent the human form and are supplied with the wrappings or cinctures under discussion.

Other vestiges represented by knobs or spurs, the former around the rim and foot, and the latter, usually two, on opposite sides near the base, are not so clear, but may be referred to costume and parts of the body.

Whether the hourglass-shaped pottery braziers may have been used to deposit the remains of high priests, or other important personiages, 
appears to be a matter worthy of inquiry. The relationship in form between the braziers and the mortuary vases and their general agreement in decoration show at least that they liave some concept in common.

Salugun ${ }^{1}$ states that the Mexicans put the ineinerated bones of the nobles in an urn, with a chalchiutl, and buried them in a room of the house and every day they placed oflerings on the sepuleher. Also: "They burnt the belongings of the dead because they pretended that these things then went to the land of the dead."

According to Brantz Mayer, the 'Tlaltelolco vases contained skulls when found, and if only this portion of the body was inurned, may not the skulls be those of saerifices placed in a brazier for interment?

The cinerary urns of 'Tlacolula were for burial of priests. Chavero ${ }^{2}$ figures one of these, a seated being with hands on the knees, an elaborate girdle, ear plugs, and modified animal lieaddress sloowing a row of teeth. Breath signs also depend from the mouth. It is probable, and Seler ${ }^{3}$ agrees with me, that the braziers were sometimes used as mortuary urns for the burial of a cacique.

II. Censers for Special Use.

\section{PORTABLE.}

(a) The solidarity and pervasiveness of the aboriginal religion of Mexico is strikingly shown from the observations of the cluroniclers, who state that the people were required to reenact in their houses, in abridged form, ceremonies following those lheld in the central religious edifices, and from surle glimpses one may gather an inkling of the tedious rites of the domestic cult. Not even among the Puelolos, where all artivities are regulated by or tinged with the system of religious observance, has such a binding power been displayed as in Mexico, where eaclı loouse was a temple in miniature.*

Thus the domestic eult repuired sufliciently elaborat e paraphernalia and apparatus to by priestly law and appliable to tho innumorable ceremonies of the religious ralendar as well as to dasses of persons, as the morehants, or to fraternities. Since the common act of all observance was the burning of incense, the domestie censer was a vessel whose use was alnost universal.

It is unfortumate that no description by Salagun, or other writers, reveals the form of the domestic brazier-censel of the Nahuas, but

1 Work cijted, 1. 224.

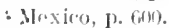

${ }^{3}$ Intter of $A_{\text {prii }} 13,1911$.

- "las casas tells us that when the Guatemalans built a new house they were careful to dedicate an apartment to the worship of the houschold gots; there they burned ineense and offerel domestie sacrifices "lpwn an attarerected for the purpose." J3ancroft, Native Raees, vol. 2, p. 786. Las Casas llist. A pologetiea At. S. (ap., 124. 
as none of the utensils of pottery recovered shows a definite class referable to braziers, it appears likely that they were not of fixed form, any suitable vessel being employed.'

Possibly in the practice of the domestic cult the forms of the temple apparatus were copied, and the lland censer, to be deseribed later, as well as a small hourglass-shape brazier may have been used to some extent, though as a rule in all primitive religions most of the eult apparatus is esoteric and belongs to the fane and priesthood, not being seen by the uninitiated except on oceasions of public ceremony.

A small terra-cotta brazier-censer from excavations in the Calle de las Escalerillas, City of Mexico, and which may have been of this class, is shown (pl. 8 b), and another from the pool of Chapultepec, near the city, shows a much conventionalized form (pl. $8 \mathrm{c}$ ).

Another consideration which bears on the effectiveness and to some extent the form of the censer is the ventilation required for the draft, as in a stove. The Mexicans had properly solved this problem by making openings, ornamental or otherwise, in the walls or the bottom of the ineense vessels. Gum-resins, such as copal, do not burn readily, and it was eustomary to throw these substances in the form of powder or small pellets upon live coals from the great permanent brazier fires or from the domestic hearth, which was regarded sacred not only by the Mexicans, but by all peoples below the plane of enlightenment.

(b) Tripods.-In the non-Nahuatl portions of Mexico, however, generally south and east of the Naluatl area, the portable censer is more commonly known, both from survivals and from the ancient examples which have been recovered from the ruins. Here the form is generally a tripod vessel, the feet hollow, modeled in a great variety of grotesque shapes, supplied with rattles, or solid and plain.

Doctor Plancarte found in the Matlaltzinea (Pirinda) area in the Valley of Mexico a specimen with three legs and having perforations of triangular and circular shape in the bottom. This authority says that the censer appears in his catalogue as a utensil of transition between the temple and the hearth, but it may belong properly to the cult, though such were used in the houses "para sahumar a los recién llegados y viajeros ó a las personas principales," 2 to fumigate those recently arrived and wayfurers, or important persons.

Some Costa Rican censers have also lids, as in the Japanese koro and the Chinese allied form, and are remarkable examples of the potter's craft, an illustration of which, as well as one of the tripod class from Guatemala, have been kindly furnished by Dr. Walter Lehmann. (PI. $s d$ and pl. 9 a.)

1 See Seler, work cited, vol, 2, 1904, p. 946, fig. 42, for forms found in the Calle de las Escalerillas, Mexico.

${ }_{2}$ Catálogo de la Coleccion del Señor Presbítero Don Francisco Plancarte, formada, con la colabracion del Dueño, por el Director del Museo Nacional de México. México, 1892. Exposicion Historlco Amercana de Madrid, Para 1892. Sección de México. 
The writer puchased in Oaxaca in 1899 a tripod incense burner of terra cotta, the rim decorated with a pair of masked human figures witl upraised hands, a pair of birds, two flowers, and two U-shaped figures, probably snakes. 'The figures on the inner and outer rim and bottom of the bowl are painted rudely with white, black, and a blue resembling ultramarine. The figure in the bottom is evidently

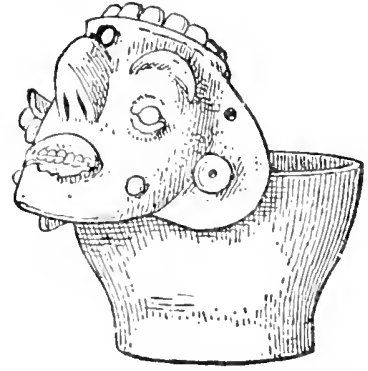

FIG. 5.-BOWL CENSER, LACANDoNes, Chipas, Mexico.

a sum symbol. I was informed by the dealer that this vessel was used by the Indians for burning copal and that the figures were "santos" of the Indians. Diameter, 7 inches; height to rim, 7 inches; to headdress of figure, $9 \frac{3}{4}$ inches. (Cat. No. 204692, U.S.N.M.) (Pl. 9 b. $^{1}$ )

(c) Bowls.-The Lacandones of Chiapas, Mexico, observe a complicated incense rite yearly, when new incense burners are made and consecrated to the gods. ${ }^{2}$ The censers are of homely vase or bowl form, painted black, white, and red with native colors, have a mask projecting like a bowsprit from the edge, and are provided with holes to insure ventilation. (Fig. 5.) It is customary to place in the open mouth of the mask offerings of food and drink and to burn nodules of copal in the ressel. ${ }^{3}$ The copal nodules are formed and stuck to a board having a handle at one side, and they are symbolically male and female, resembling in form the nodules of copal found in excavating the ancient sites of Yueatan, and reminding one of the joss sticks and pastilles of the Orient. (Fig. 6.) In the censer are placed jate figures representing the

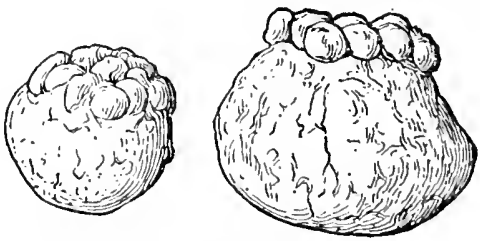

Fig. 6.-Copal nodules, Lacandones, ChiaPAS, MEXICO.

gods of the Lacandiones, and over them the copal is burnt. Palm leaves waved in the smoke are thought efficacious in driving away disease. The ceremony and the ceremonial use of the Lacandones censer is a remarkable cxample of the survival of an ancient custom, and throws light on much that was unknown of the cult practices of this region.

1 For discussion of the headlress of an image on a Oaxaca censer, see Seler in Bulletin 25 , Bureau of American bithology, 1 (n) 1, pl. 35.

2 Tozzer, A comprirutive study of the Mayas and lacandones, l'ubl. Arch. Inst. Anerica, New York, $1 ! 07, \mathrm{~T} .107$.

Maler, Mem. I'eaboly Mus., vol. 2, No. 1, p. 2s.

Selcr, work cited, 134k, vol. 3, pp. 545-549.

a Stephens stales that incense was burnl on the stone projecting from the unouth of a gigantic mask, the "Cara Cigantesea," at Izamal, Yueatan (St"phens. Yucatan, vol. 2, pp. 234-236), suggesting lihe lood offerings in the mouth of the mask on the Lacandones braziers. 
The Guatemalan portable incensarios are frequently spinose bowls with a head on one side. They all bear evidence of burning resin, are of crude, coarse clay, and some specimens have lids. ${ }^{1}$

The censer has not survived among the Mayas as it has among the less modified Lacandones; but L. II. Aymé sent to the National Museum from Merida, Yucatan, an incense burner of pottery of gray, coarse paste, washed brown on the interior and red on the exterior, and having the form of an incurved bowl mounted on a foot, and two rows of holes punched through the body to insure ventilation. (Fig. 7.) In the bottom of the bowl is a dab of the red paint with which the exterior is washed. (Compare Oaxaca censer, pl. 9 b.) This appears to be a vessel for burning incense in the house. (Cat. No. 738s5, U.S.N.M., original No.17.) Diameter, $4 \frac{1}{4}$ inches; height, 4 inches.

\section{Gesture CEnsers.}

The third class of censers comprises those held in the hand and used for wafting incense in a certain direction or toward any object to be incensed. It would seem that the requirement for worship toward the cardinal points has given rise to the hand censer, which in its most developed form resembles a shallow dipper with a long handle. There are specimens which may show a development of this form from a bowl

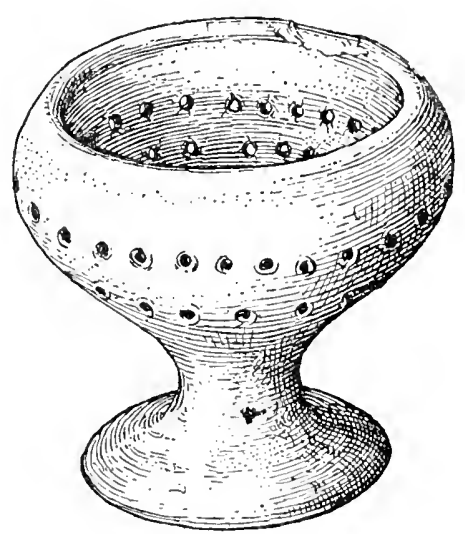

Fig. 7.-VASe Censer (MODERN), MERida, Yucatan. Collected by L. H. Aymé. or tripod censer, as suggested by:

(a) A specimen from Oaxaca, in form of a flaring bowl of brown unpolished ware having a projection from one side and a starlike handle with four prongs, appears to be a censer and to stand morphologically between the bowls and hand censers. It was collected by E. O. Matthews, and is $3 \frac{1}{4}$ inches in diameter and $2 \frac{1}{2}$ inches high. (Cat. No. 215137, U.S.N.M.) (Pl. 10 a.)

(b) Openwork pottery tripod ressel, one leg of which is extended to form a handle. This type is usually of extremely good art, and consists of a cup-shaped bowl piereed with beantifuly excouted openwork resting on two round feet supplied with rattles, the curved handle terminating in a flexed arm, which forms the handle and third foot. The specimen is from Oaxaca." (Collected by L. II.

1 See JTough, in Report of the Madid Commission, 1992, Washington, 1995, p. 354.

Seter, work eited, 1908, vol. 3, p. 625, figures a spinose vessel of this construetion.

2 Rattle-foot eenser of brown elay with design perforated and ontlined with seratehed lines and having bosses on opposite sides. The end of the handle is moteled in the form of a Hexed arm, the hand clasping the cylinder. The feet and handle are set in on stubs. The triangular ventilating orifices forming the openwork design have been punched out with a tool which leaves the edges slightly rough. Length, 8 inches; height, 4 inches; diameter, 37 inches. 
Aýmé. Cat. No. 131452, U.S.N.Mr.) (Pl. 10 b.) A number of similar censers have been found.

(c) Among the Lacandones of Chiapas, according to Tozzer, the ladle incensario occurs, but plays an unimportant part in the rites and is used only in the ceremony when the new braseros are installed. It consists of a dipperlike vessel with a head on the side next the handle, and is called akna, "the mother." Tozzer discusses this type of incensario ${ }^{1}$ and says that the handle terminates in a hand in which offerings of food are made, while incensarios of the older culture had serpent heads. A handle of an incensario from Honduras is figured in plate 19 of Tozzer's work. Seler ${ }^{2}$ figures specimens from Coban in the collections of Sarg, Sapper, and Dieseldorf, in the Museum für Völkerkunde, Berlin, that appear to be incense spoon handles. They are of animal forms, are short, and some of them have a foot; and, while no vessels to which they were attached have been found, it is probable that the identification by Seler is correct.

From the Zapotec area, Oaxaca, numerous examples have been found of a crude ladle of coarse, dark-gray pottery, the bowl of which has a flat bottom with six or seven holes punched therein. The handle is hollow and is truncated squarely at the end. (Cat. Nos. 109813, 109814, U.S.N.M., Oaxaca, Mexico. ('ollected by L. H. Aymé.) (Pl. $10 c .^{3}$ )

Kingsborough ${ }^{4}$ figures a specimen in the fourth volume of his work. The presumption is that these are censers for domestic use.

Through the courtesy of Dr. Walter Lehmann, a photograph of a handle censer from Guanacaste, Peninsula of Nicoya, Costa Rica, has been secured. The specimen is from the Velaseo collection, National Museum, San José de Costa Rica. (Pl. $12 c, d$. ) Its resemblance to the Tahuatl censer ladle is apparent, and Lehmann cites its locality as "the Mexican enclave of the Peninsula Nicoya." In point of specialization it is hardly so far adranced as the Nahuatl variety, its decoration is southern, and in some respects it approximates the Zapotee modified tripod. (See pl. 10 b.)

Prof. Marshall II. Saville, while carrying on the work of the Meyo Expedition to Eeuador, discovered at Manabi a dipperlike vessel, the end of the handle terminating in a clenched fist, resembling in this respect some of the censers found in southern Mexico. It is very small (3! inches long) and is classed as a censer. ${ }^{5}$

1. Work elted, 1907 , p. 110.

2 Work cited, 1904, vol. 3, pp. 604-605.

3 Measurements: 1)iameter, 5 incles; height, $1 \frac{1}{8}$ inches; length of handle, $4 \frac{1}{5}$ inches; dianeter of handle, $11^{3}$ inches.

- Intiruities of Hexico, London, 1830 -14ts.

${ }^{6}$ Contr. Sonth Amer. Arch. The George G. IIeye Expeditlon. Antiquities of Manabl, Ecuador. Now York, 1907 , vol. 1 , pl. 54 , fig. 5 . 
Small ladle forms found in the huacas of the Guetaro Indians of Costa Rica are called incensarios, but examination of the specimens in the Arellano collection, exhibited at Madrid in 1892, ${ }^{1}$ showed only one bearing traces of fire. There is, however, a mask on the handle adjoining the bowl, and the weight of opinion must class them as incensarios. Lehmann has discovered ladles of this form near Cartago, Costa Rica. (Fig. 8.)

(d) The most familiar object of this class and the most highly developed is the Nahuatl hand censer spoon having a long handle and decorated with painting and sculpture. This censer was held in the hand of the officiating priest. and the fumes of the copal or other incense wafted toward the figure of the god. They are rather frequently found in the Nahuatl area of Mexico, and numbers were unearthed in the trenches near the Cathe-

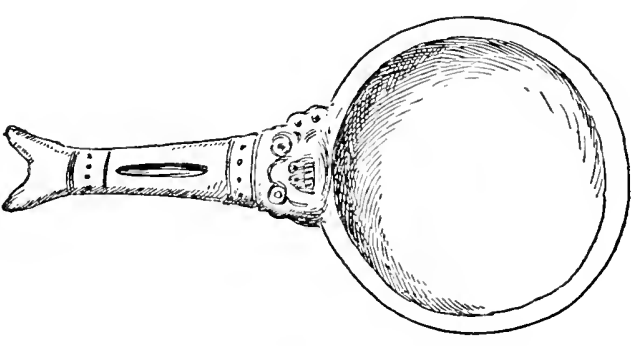

Fig. 8.-Lade censer, Guetaro II uacas, Costa rica, AREllaNo COLLECTION.

dral plaza in the Federal district some years ago, ${ }^{2}$ several having been brought to the United States by collectors. Their mode of use may be seen in numerous instances in the picture writings, where the characteristic extended arm holding the censer is graphically depicted.

Sahagun describes the oflerings made by the Mexicans in their calpulle, and mentions that the satraps (attendant chief priests) offered incense clay and night in the temples at certain hours.

They used for that purpose censers of terra cotta in the form of a kind of skillet of medium size with a hollow handle of the largeness of a vara in measure and of the length of the arm up to the elbow or a little more, having within little stones which served as rattles. The censer was ornamented with sculptures which are pierced at intervals from the middle to the base. They took in it lighted coals from the fire and they threw on it copal; they approached the statue of the demon and they elevated the censer toward the four eardinal points; at the same time they incensed also the idol. When this was done they threw the coals on the fire. The same practice wats imitated by the people in their houses, morning and evening, before the statues which they had in their chapels or in their courts. The parents taught their children to make the same evening and morning. ${ }^{3}$

Sahagun also tells us that at the

feast of Tezcatlipoca everyone carried perfume pots. They made fire in the temple in order to have coals. They carried also copal and censers of terra-cottalike pots,

I Alfaro, Anastaslo. Catalogo de las Antiguidades de Costa Rica exhibidas por el Exemo. Sr. 13. Julio Arellano. Exposicion 11istorico-Americana de Matrikl. Madrid, 1592, p. 17.

Hough, Ancient Central and South American Pottery in the Columbiun IIstorical Exposition at Madrid In 1592. Report of the Madrid Commission, 1892, Washington, 1595, p. 347.

2 Seler, work cited, 1908, vol. 2, p. 856.

3 Sahagun, work cited, p. 183. 
piereed and much worked, that they called tlcmaitl (tlctl, fire; maitl, arm). They had also all kinds of copal, and they prepared portions for use in the ceremonies customary in the service of that god. The chief priests, when a certain moment of the service eame, took coals in their censers, threw on them eopal or incense and incensed the images of Uitzilopochtli that they had installed in the temple a little while before. This ceremony was not only made in this place, it was repeated in all the houses by their proprietors, who incensed the images of the gods which they had at home. When they had finished the incensing they went to deposit the ashes in a round hearth, ealled tlexictli (tlctl, fire; xictli, navel or cord, leather band), which was placed in the midst of the court where it was elevated two spans above the soil. ${ }^{1}$

The Cnited States National Museum collection contains numerous handles of the tlemaitl, all of the serpent design ${ }^{2}$ which was that commonly used by the Nahuas, and a bowl with a portion of the handle remaining, collected by Dr. Edward Palmer from a cave at Dos Caminos, 2.5 miles east of Acapulco. The latter specimen is of coarse, brown paste, the handle a hollow tube, the bowl even in outline and perforated with a design consisting of four triangles, arranged as in the Maltese cross, repeated three times, and with a triangle in cach of the broad spaces between the four-part design. A plain circular area is left in the bottom of the bowl. The under surface has bands ornamented with small papillæ, and on one sidle of the bowl, near the edge, project two spurs, perhaps rudimentary feet. (Diameter of bowl, $7 \frac{3}{1}$ inches; height, $2 \frac{1}{2}$ inches. Cat. No. 173069, U.S.N.M.) (Pl. 12 a.) The handle is from the Hill of Tepeyac, Mexico, D. F., and was collected by W. W. Blake. It is tubular, of red paste, and shows obscure coiling marks. The head of the fire serpent has extended tongue, open mouth, projecting teeth, and a band across the neck. The mouth of the serpent does not communicate with the hollow of the tube. (Length, 12 inches; diameter, $1 \frac{1}{2}$ inches. Cat. No. 99081, U.S.N.M.) (Pl. 12 b.)

The writer may be pardoned for introducing at this point for comparison an oriental hand censer which presents remarkable similarity to the Mexican hand censers just described. The specimen is from Jipan and is rescribed as an "ancient hand censer," used in temple worship for directing the smoke of incense toward the inages of the grods. A dragon is coiled about the handle, and the lattor in turn passes around the middle of a constricted vase with foot. It combines the sedentary koro with the hand censer, more fully than the Chinese type. (Cat. No. 6330, U.S.N.M. Collected by the late Gen. O. E. Wood, U.S. Army.) (Pl. 11.) The Clinese employ a similar' hand censer, but more conventionalized in design.

(e) A tubular incense apparatus, through which or from which smoke may be blown by expulsion of the breath, was anciently used in Mexieo, as witnessed by the seulptures of the Palenque altar and

I Sahagun, work citirl, p. 101.

2 The handle sometimes terminated in the talons of the eagle. See Scler, work cited, vol. 2, 1908, p. 862. 
drawings in the Manuseript Troano figured by McGuire. ${ }^{1}$ This pipe censer is found on ancient sites in the region west of the Rio Grande and south of the great breaks in New Mexico and Arizona. It is a hollow, truncated cone, usually of tuff, often showing traces of red and yellow pigment and from 6 to 14 inches in length, the diameter varying from $1 \frac{1}{2}$ to 4 inches. It was found in the larger rooms of ruins, associated with small painted mortars, decorated slabs, and other cult apparatus, and which almost invariably show traces of fire. Its connection with the small tubular "pipes," either straight or frequently bent at a slight angle, found north of the "breaks" and in use at the present day in religious ceremonies by the Pueblos, has been suggested by Dr. J. Walter Fewkes, who says that by interprotation of the Hopi name it is a "cloud blower." Dr. Fawkes informs me that the large pipe used in the Winter Solstice ceremony and called the "great snow pipe" is made especially for the ceremony and has a capacity of about half a pint of the sacred tobaceo mixture. It is of clay, not decorated, and the object of its use is to create a big smoke cloud as a petition for snow, exemplifying the "gesture prayer." The writer has observed the use of such tubes in Hopi ceremonies, where the celebrant fills the pipe with aromatic herbs, lights it from the kiva fire, and, inhaling, blows a compact cloud of smoke as an offering to the rain gods or other beings who move in the sky behind cloud masks. The connection is obvious, but often the large size of the southern blower would prevent indivilual use as above, and some other method of producing the smoke or incense cloud is indicated. Several specimens in the National Museum have orifices through the wall of the blower in its lower half, and one specimen found by the Museum-Gates exploring expedition of 1905 has a series of holes around the base near the lower edge. These orifiees may be designed to promote the draft, which may have been increased by the insertion of a reed tube, and they are analogous to the triangular cuts through the basin of the incensarios found in the Calle de las Escalerillas and in other parts of Mexico, as well as those vase forms from the Lacandones, the ancient Mayas of Yucatan, and the ancients of the Peninsula of Nicoya, Costa Rica. This resemblance, which may seem a mere detail, is significant.

A specimen of the tubular cloud-blower in the National Museum is made of friable tufa deeply colored by the effects of fire. The cavity has been drilled from both ends, the upper portion of the eavity being much larger than the lower, as in the smaller pipes. A shoulder is formed in the upper extremity of the pipe, and throur? this shoulder a diagonal hole has been perforated into the bowl of the tube, in this way resembling very mueh the treatment of a Ilopi

1 Pipes and Smoking Customs of the American Aborigines, Ann. Rep. U. S. Nat. Mus., 1\$s;, p. 37, and frontispiece. 
field oven with its draft hole. Inother perforation extends horizontally through the wall neal the base of the pipe. The exterior of the pipe has as fine a finish as the material will bear and is well

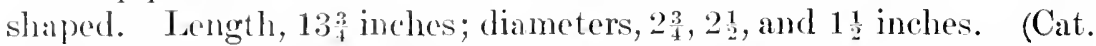
No. 9s22s, U.S.N.M., New Mexico. Collected by E. W. Nelson.) (Pl. 13 a.)

Another cloud-blower is of coarse tufa of yellow-brown color, excavated from both enls, giving an hourglass-shaped section; form, a truncated conc with raised molling near larger extremity. Traces of rortical bands of red, yellow, and black pigment appear on the surface. Ilalf of the blower is missing. Found in a ceremonial room of the large puchlo ruin on Spur ranch, near Luna, Now Mexico. Length, s $\frac{3}{4}$ inches; diameter, 4 inches; diameter of mouthpiece, $3 \frac{1}{4}$ inches; lower end, 2.2 inches; orifice, $1 \frac{3}{4}$ inches. (Cat. No. 231904, U.S.N.II. Collected by Walter Ilough.) (Pl. 13 b.)

In his important and valuable paper on aboriginal pipes and smoking rustoms, ${ }^{\prime}$ Mr. J. D. MeGuire has brought together by far the largest collection of information on this subject. The pipe, this author has pointed out, anteclates the use of narcotic herbs, such as tobaceo, and he conclurles that "the importance of smoke appears to have been chiefly, if not entirely, due to its supposed medicinal properties." Mr. MeGuire also points out that the offerings of incense by the Aztees to the Spanish invaders under Cortés were in many respects similar to the familiar pipe customs of the Indians, and pipes of like shape are traeed from southern Mexico to British possessions in the north.

It is manifest that the custom of smoking did not originate in gustatory enjoyment, but following along the line of the development of the fire eult, smoke liad an esoteric or sacred meaning. The first oflerings would be from a static fireplace, such as the camp fire, and as progress was made in the arts of life the earing for fire in portable appliances would grive rise to braziers in great valriety-as, for axample, the bowl-shaped censer of the Lalcandones and the handled censer of the Nahuatl, which correspond respectively, to the static and handled censers of Tapan and China. The swinging renser of Europe is evidently a development of a sodentary vase form. The pipe itself seems to be a development from a sedentary form which has survived in the "great pipes" sometines oceurjines among the North American Indians. As an outgrowth of chviromment, culture, and customs, smaller pipe forms were alopted and the original intention of smoke offerings was much modified by individual eireumstances. We have also an interesting analogy between the handled censer in Mexico and the peace pipe used in eremonies by the North American Indians, 
both utensils showing, it is presumed, the likeness due to similar needs rather than to direct acculturation.

The following is a description of the specimens figured on plate 14: Pipe of gray vesicular rock, shallow bowl, uniform tube leading to center of bowl. Diameter, $1 \frac{1}{4}$ inches; height, 2 inches. (Cat. No. 212609, U.S.N.M.) Scorse ranch, near Holbrook, northeastern Arizona. Collected by Walter Hough. (Pl. 14 a.)

Made of purple vesicular lava; bowl not much enlarged; tube of large caliber. Diameter, $1 \frac{1}{8}$ inches; height, $1 \frac{3}{4}$ inches. (Cat. No. 212102, U.S.N.M.) Petrified forest, Arizona. Collected by Walter Hough. (Pl. 14 b.)

Of yellow sandstone; bowl large and conical, joined by a small orifice at apex of cone formed in the base. (Cat. No. 149435, U.S.N.M.) Arizona. Collected by R. J. Coyne. Diameter, $1 \frac{7}{8}$ inches; height, $2 \frac{3}{5}$ inches. (Pl. 14c.)

Of dense, vesicular lava, brown to blue in color, finely finished; the bowl very deep. Diameter, 1 $\frac{1}{8}$ inches; length, $2 \frac{3}{16}$ inches. Petrified forest, Arizona. Collected by Walter Hough. (Cat. No. 212131. U.S.N.M.) (Pl. 14 d.)

Pipe of pottery; brown color, surface highly polished, bowl deep, meeting smaller orifice perforating its bottom. (Cat. No. 156132, U.S.N.M.) Length, $2 \frac{7}{8}$ inches; diameter, $\frac{5}{8}$ inch. Sikyatki, Arizona. Collected by J. Walter Fewkes. (Pl. 14 e.)

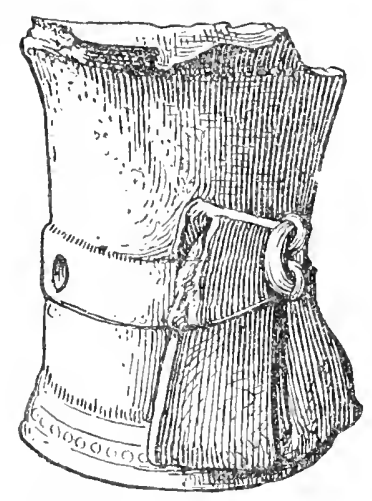

Fig.9.-ANCIENT POTTERY BRAZIERCENSER, CITY OF MExICO.

Pipe of pottery; exquisitely finished, brown color, stem squared, bowl swelled and terminating in a collar. Length, $2 \frac{1}{2}$ inches; diameter, $\frac{7}{8}$ inch. (Cat. No. 213250, U.S.N.M.) Awatobi, Arizona. Collected by the Museum-Gates Expedition, 1901. (Pl. 14f.)

Pipe of brownish tufa; bowl and stem of equal length, side of bowl decorated with cross formed by small holes drilled in the material. Length, 23 inches; bowl, 1 inch by 3 inches. (Cat. No. 23476s, U.S.N.M.) Jemez, New Mexico. Collected by Mrs. Matilda Coxe Stevenson. (Pl. 14 g.)

Pottery pipe exquisitely finished, mouth portion flared; body ridged as though wrapped with cord, except collar portion at the forward end. Length, $2 \frac{15}{16}$ inches; diameter, $\frac{5}{5}$ inch. (Cat. No. 156154, U.S.N.M.) Awatobi, Arizona. Collected by J. Walter Fewkes. (Pl. 14 h.)

Pipe of dark gray stone, well finished; bowl, shallow cone; base flattened and expanded. (Cat. No. 234769 , U.S.N.M.) Jemez Plateau, New Mexico. Collected by Mrs. Matilda Coxo Stevenson. Length, $2 \frac{1}{8}$ inches; diameter, 3 inch. (Pl. 14 i.) 
Pipe of brown pottery consisting of a flaring stem; circular bowl surmounted by a broad collar ormamented with cross-shaped design in perforations and scratched on the surface. Length, $2 \frac{1}{2}$ inches; diameter, 14 inches. (Cat. No. 244762, U.S.N.M.) Jemez Platean, New Mexion. Collocted by E. L. Hewett. (Pl. $14 j$.)

Pipe of pottery, quadrangular shape, rounded at the base and with a collar near the mouth, decorated on two sides with the light-
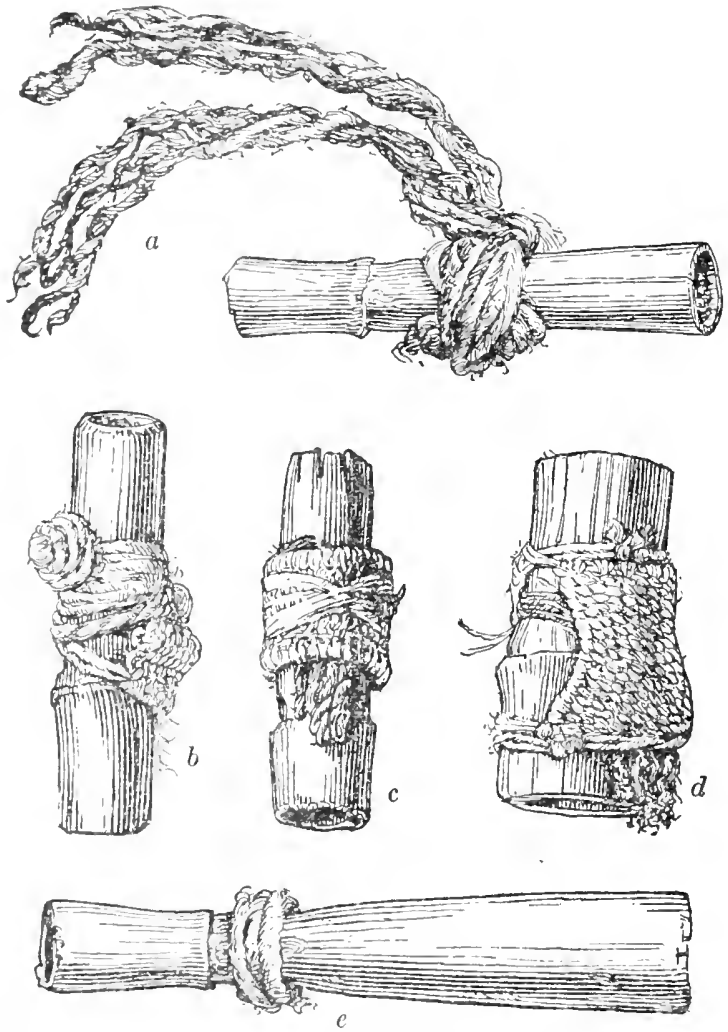

Fig, $10(a, b, c, d, c)$.-ReED Cygarettes Witil cincture, ARizona. (OLLECTED BX MOUGII AND COOLEY. have not had fire put to them and obviously the offering is by implication. In some cases, however, the cigarettes have been lighted at the time of offering, as in certain shrines olsserved in caves on the Bhe River, Arizona, these usually being the larger canes of functional size and not the miniature tubes which occur in such great profusion.

'The (rigarettes (fig. 10) are girdled with strands of white or dyed cotton cord; miniature blankets and somotimes beads or feathers are attached, the object inthe mind of the worshipper being to duly clothe 
these offerings in consonance with the belief that they were animate, and, further, that they represented the human body, as has been pointed out with regard to the censers and braziers. Rudiments of this girdle are seen on small tubular pipes from northern Arizona (pl. $14 f, h, j, k$ ), which appear to show their relation to the cane incense tube, and it is probable that the longer plain tubular pipes were girdled with cord and feathers at the time of offering, as in some modern Pueblo examples.

Similarly, some of the Mexican pottery censers of hourglass shape bear a girdle in relief representing the cord tied in a symbolic bow. (Fig. 9.)

There is also a close connection with respect to the cigarette between the Mexicans and the Pueblos. Abundant references in the writings of the chroniclers show that cigarettes cut from reeds, painted in various patterns and colors, filled with different kinds of odorous herbs and other aromatic substances pulverized and mixed together, were smoked ceremonially.

\section{SWINGING CENSERS.}

(a) The swinging censers which remain to be discussed are not indigenous to the Western Hemisphere, but have been introduced by the religious orders. The Museum possesses a specimen from the Oxchiri Indians of Chiapas, Mexico, which shows an interesting adaptation of native materials and art. It consists of an hourglass-shaped basket of ixtle cord twined over a coiled rod. At the

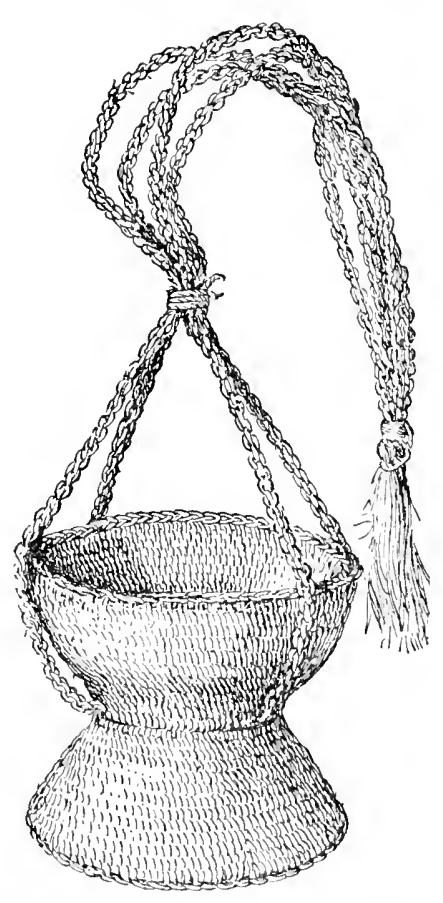

Fig. 11.-SWINGING CeNSer ilolper, Indins of Oxchri, Chipas. ColLECTED BY L. II. AYMÉ. narrowest portion are attached four braided cords which are bunched at the ends and form a sling by which the censer may be swung. These cords can be drawn together' with a sliding ring. The incense, of copal, is burned in a bowl of earthenware which fits in the larger concavity of the basket, and the apparatus is presumed to have been used in the celebration of mass in the poor country churches attended by Indians not possessed of a metal censer. Diameter, top, $5 \frac{3}{4}$ inches; bottom, $5 \frac{1}{4}$ inches; height, $4 \frac{1}{2}$ inches; length of cords, 23 inches. Collected by L. II. Aymé. (Cat. No. 76895, U.S.N.M.) (Fig. 11.) 


\section{REMARKS ON THE CENSER IN SOUTH AMERICA.}

The apparatus discussed in this paper is most prevalent in central and eastern Mexico, less so in Central America, and gradually diminishes through the South American cultures. Information concerning South American cult apparatus is extremely limited because the historical and linguistic nexus has been lost, and no knowledge is recoverable from a vocabulary of symbolic art, so rich in Mexico. The tripods and stool forms of Chiriqui, described by Holmes, ${ }^{1}$ some of the carved stone metates, pottery vessels of tazza and tripod forms of Echador and Peru may have been designed as censers, but beyond their relationships in shape and in some features of construction and adormment no approximately conclusive data can be put forward concerning South American censers. Incense was offered on the figure brazicrs of Ecuador, and no doubt incense was known in Peru and Bolivia, but little has been published of the vast stores of relies from this area in museums.

\section{DISCUSSION OF THE USE OF INCENSE IN WORSHIP.}

The offering of ineense is almost universal. Tribes which have reached a stage where recurrent rites are observed, and where ceremonials have attained some complexity, make use of this feature of the fire cult, and below this grade of culture individual or family acts of worship often show the employment of incense or fire offerings.

While fire may be primary in regard to the origin of the idea of incense, it beeame secondary as applied to advancing cults; that is, offerings were not confined to the communal house or camp fire, but wre made on special hearths or in special apparatus. Nevertheless, no incense was so offered that was not ignited from a sacred fire; that is, one carefully prepared to insure purity, and secured from the ancient wood drill, from lightning, lens, mirror, or other consecrated or supernatural source. New fire is kindled by the Lacandones of Chiapas by wood friction for use in consecrating consers and igniting copal burned at that time.

'The new fire is thought by the Lacandones to be eflicacious in healing sickness, the soot collection on palm leaves being the common method, but a stone hoated in the fire and used to warm water renders the latter a panacea for fever. ${ }^{2}$

The phenomena which accompany combustion are so familiar that the man of onr times passes over the marvel of smoke, flame, and ashes without analysis or comment. To the man of a certain stage of antranement we may suppose that the wonder of the birth,

1. Inclent Art of the l'rovince of Chirigui, Colombia. Sixth Annual Report of the Bureau of Ameriean Ethnology, 1 siss.

${ }^{2}$ Tozzer, work cited, 1907, p. lot. 
life, and death of fire was a vivid reality; it is evident from a survey of the widespread remnants of the fire cult that the steps of this mysterious physical manifestation impressed his mind, determined an attitude (creed), and predicted a course of action (cult) in consonance with the observed facts of fire action.

The lore of smoke is extensive, embracing individual acts and collective acts relating to fumigations both sacred and profane. The ideas relative to the purification, healing, scaring of demons, removing of evil influences, etc., effected by smoke have been in the minds of votaries of fire worship in divers countries and periods, and it is even probable that fumigations alluded to by Shakespeare, in Much Ado About Nothing, where a perfumer is ordered to smoke a musty room, or when in The Taming of the Shrew the command is given, "And burn sweet wood to make the lodging sweet," there was also involved some antique belief in dispelling bad influences, which may be classed as primitive sanitation.

The use of smoke in worship, however, seems to have arisen from the observation that this ghostly element of combustion dissolved in the air, passing away from sight mysteriously, like fog and cloud vapor, thus supplying a messenger to the unseen. It must not be forgotten also that to unspoiled senses the odor of smoke would be strikingly pungent and perhaps the most remarkable attribute of fire, a potent and far-reaching means of calling the attention of supernatural beings, propitiating or frightening them. The Homeric and Jewish idea was that a sweet savor was pleasing to divinity, and this appears to be the most widely diffused idea connected with the burning of incense in worship, while offerings to the fire which at one time were customary may have been for the double purpose of pleasing the spirits with incense, and of feeding them. The offering was consumed by the fire and disappeared from human sight, thus being analogous to the practice of throwing offerings into springs or rivers.

Mr. J. N. B. Hewitt informs the writer that the Iroquois use tobacco smoke to make authentic a petition, and states that in the New Year ceremony the Life God, whose vitality is supposed to wane during the year, presents a petition for restoration, and in order to give value to his petition a portion of the rite is marked by the burning of tobacco for this purpose. The solemn ceremonies also connected with the calumet may involve this idea. The calumet is passed around in order of official seniority during the council and he who holds it affirms his speech by blowing a cloud of smoke. Similarly, in the ratification of peace, the pipe was an important adjunct, without which the terms would not be binding. It is probable here, as in many other rites connected with the use of incense, that the smoke is designed to open communication with 
the spirit world by attracting the attention of the intangible beings. Mr. Hewitt says, however, that it is the tobaceo rather than the odor that is offered as a sacrifice to the deities; that is, the soul, or the reality, of the tobacco is what reaches the gods. By means of separate acts there is a twofold use of tobacco in a peace or other council-the one to compose the minds of the councilors and the other to invoke the good-will of the gods to whom it is offered in sacrifices.

Incense was probably at first the smoke of wood or of leaves, then later selected, compounded of several materials, and made sacred by rites." It was finally sought all over the world, and a commerce in "frankincense and myrrh" was one of the chief agencies in bringing a knowledge of the people of the Tropies to those of northern zones.

The incense from South America, according to Humboldt, ${ }^{2}$ was from the Icica gujanensis and Icica tacamahaca. That used most commonly in Mexico and Central America was the gum of the Protium heptaphyllum, called copal by the Spanish. This tree is also a Bursera, from which genus the most precious incense gums of the world are derived. "The Mexicans and all the inhabitants of New Spain made use (which they pursue yet somewhat to-day) in their offerings of that incense of copal, a kind of white gum which they call copalli, for incensing their gods. They had not recourse to our true incense, because it was not found in their country. It was copal that the satraps used in the temple and everyone in the private houses, as we have said above." 3 Tozzer states that the sap of the rubber tree was used by the Lacandones. The wood and leaves and the resins of the pine trees in Mexico had important cult uses. Pine needles are used as incense by the Hopi, as they are by the Tibetans.

In the descriptions of the home life of the Mexicans, transmitted by the early chronichers, it is stated that vases filled with smouldering incense diffused their perfumes through the rooms, ${ }^{4}$ and numerous montions of such usage give the impression that it was customary to burn odorous substances as a matter of refinement and for personal pleasure, just as tho use of tobaceo became secularized.

\section{INCENSE MATERIALS.}

In the course of time, with the growth of ceremonies and the increasing complexity of culture, incense hecame differentiated into kinds and preparations appertaining to the various deities and celebrants. There may have been many prescribed varieties of incense, and of

1 The Jews had at first 4 ingredients and later 13 . Numbers, xv1.

2 Cosmos, vol. 2 , p. 204.

ahagun, work rited, p. 183

- Bencroft, Nallve laces, vol. 2, p. 573. 
those whose names have survived in the chronicles are copal blanco white copal, with mixtures of tobacco, etc.; incenso comun, ordinary incense; and chapopopotti, bitumen, the latter used in the worship of the god of war, Huitzilopochtli, all the foregoing being employed by the Nahuas. The Mayas used copal; copal ground with maize; eaoutchouc; zacah, a kind of incense burned by priests; and chachalte, burned by nobles. ${ }^{1}$

The Mexicans, like other peoples in close touch with their environment, were acquainted with the properties of plants, and to this day the exhaustive pharmaceutic and utilitarian botany of a village market is one of the most surprising things one meets with in that country. The ancient Mexicans had thus ransacked the plant world for vegetal substances, which on burning would produce an agreeable odor, many of which are mentioned in the works of Hernandez, Monardes, and others, but whose identification botanically is almost invariably impossible owing to incomplete characterization.

Dr. S. A. Barrett informs me that at the present time the Cayapas use in Ecuador for religious feasts a sort of whitish resinous substance (copal) which comes from the interior of the country. They do not have very much of it, and prize it very highly on account of having come from such a distance. They burn this substance at the time of a deatl.

There is a great confusion as to the identity of copal, the name, according to some writers, being used to cover a number of gums. It is possible that the eonfusion has arisen from post conquest times when errors multiplied rapidly as the Mexican culture slipped swiftly into the background, for the earliest reliable chroniclers are clear as to the commonest use of the gum which we know as eopal, and whose characteristie odor would place it distinctly in the first rank of incense materials.

The following notes from Sahagun refer to various vegetal sources of incense substances burnt for the odor:

There is a plant called quauhyayaual. Its roots are long and become green at the ends. The leaves are small and round. The exterior of the plant mixed with incense acts as perfume. The root is of no utility. They find the plant on the mountains. ${ }^{2}$

There is another plant called tlalpoyomatli, of which the leaves are ashy, soft, and velvety. It has flowers. Its odor has caused it to be chosen for the perfumes which they introduce in to the reeds for smoking. Its aroma spreads far. ${ }^{3}$

This appears to be the artemesia, sage, which was a sacred plant among the Pueblos and many other tribes of Indians.

There is a small wild tree called tcocotc (Pinus tcocote), of which the root has the odor of incense when it is burnt. Only the lords and the dignitaries have the privilege of using it. Other persons are not authorized and have not the right to use it. ${ }^{4}$

\footnotetext{
1 Bancroft, Native Races, vol. 2, p. 702; Tozzer, op. cit., 1903, p. 20.

2 Sahagun, work cited, p. 753.

a Idem, work cited, p. 766 .

Idem, work cited, p. 731 .
} 
There is a tree from which exudes the white resin called copal, which is the incense offered to the gods by the Mexicans. They sell it now very much in the markets, because it is employed as a remedy and is good for a great number of things. It is produced in the Provinces of Tepequaciulco, Yonala, and Conixro.

There exists a tree called ocotzoguanitl, "resin tree" (Liquidambar styracifolia). It is high, large, and has leaves like the willow. It exudes a resin that they employ in the reeds that serve for smoking. ${ }^{1}$

Prof. Frederick Starr figures modern Mexican incense burners, and gives numerous instances of the continuance of the practice which still maintains the demand for copal, and rolls of this gum wrapped in corn husk may now be found on sale in the markets of Mexico. ${ }^{2}$ It is usually formed into a roll about three-fourths of an inch in diameter and 6 inches long, enveloped in corn husk, or wild plantain, tied at either end and around the roll with strips of fiber. The National Ifuseum has a specimen (Cat. No. 261999, U.S.N.M.) collected in Tampico by Dr. Edward Palmer. (Fig. 12.)

Tobacero was also a sacred herb, and its smoke was unquestionably incense. The wild tobaceo plant is incorporated in the mixture used as incense by the Hopi and some other American tribes. Seler states that tobaceo "played precisely the same part among the priests and

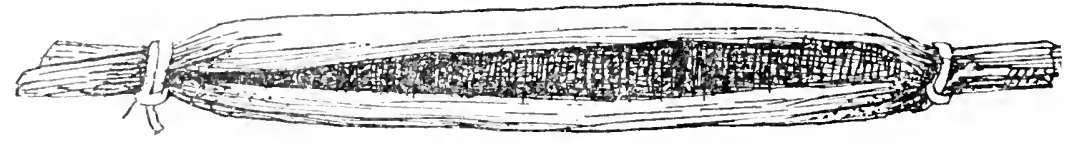

Fif. 12.-Copal prepared for market, Tampico, Mexico. Collected by Edward Palmer.

medicine men or ancient Mexico as it has from the remotgest times down to the present day among the various savage tribes of North and bouth Amorica." 3 It was powdered and mixed with incense and formed into pellets which were carried in a pouch by olliciating priests. In other parts of the Lnited States artemesia, the balsam root, cedar tops, sweet griss, and, among the Siksika, a sweet gum of some kind were burned for incense.

There must exist implements and utensils connected with the gathering and preparation of incense, but which are not recognized as such. The powdreing of copal, mixing it with tobaceo and other substances, forming it into pellets or nodules with the aid of heat, manipulations necessary to prepare the incense for formal offering, in all likelihood did not necessitate the employment of special apparatus, but was performed will clomestic utensils, such as the metate and mortar, cooking ressels or comal, the pollets formed with the hands like any plastic substance. The industry in the ancient days also

1 Sthagin, work (if, l, p. 73:3.

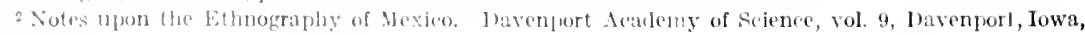
1002 .

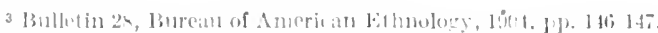

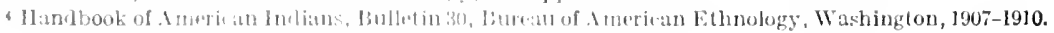


undoubtedly required the services of many persons from the sources through commerce to the consumers, who were the families (clans) and the priesthood attendant on the teocallis.

In the caves of southern Arizona there have never been found definite masses of resin or anything which might be called incense outside of the herbs contained in saered eigarettes. Nevertheless, there are often attached to offerings resinous substances which have an odor resembling that of copal.

\section{CUSTOMS CONNECTED WITH THE USE OF INCENSE.}

Some of the numerous customs connected with the use of incense are collated and introduced here. These have a bearing on the beliefs under whose sway the incense cult came to be practiced and which have an explanation far from simple, depending largely on the plane of philosophy reached, and modified by local and individual habits of thought and traditions.

Sahagun tells us that there were persons whose office was to provide copal, incense plant, censers, torehes, and wood for the temple service, ${ }^{1}$ and speaks of the Tlacolquacuilli, who were the guard of the temple Mecatlan. "They were clothed in the manner we have described for the priests - that is to say, a jacket unxicolli, and carried a calabash full of tobacco, picietl" (p. 192). Further, "the chief priest, Mexicatl teohuatzin, 'Mexican master of the gods,' was elected by the two great priests and had eharge of the hierarehy. His costume was a jacket of eloth, a conser of the form of which they made use, and a pouch filled with copal for incensing." 2 And further: "The chief priests and ministers of the temple were charged not to allow the fire in the court go out and to wake up those who had the mission of sounding the hours or those who should burn incense and make offerings before the idols. ${ }^{3}$

During the ceremony of incensing the god Huitzilopochtli each priest placed coals and chapopopotli ${ }^{4}$ incense in his themaitl and wafted the disagreeable odor toward the idol. 'The ashes were then emptied from the censers into an immense brazier called the tlexictli, or fire navel.j

Aztec monarchs were annointed, and during this ceremony burned incense to the god Huitzilopochtli. "A censer containing live coals

\footnotetext{
1 Work cited, pp. 190-193.

2 Sahagun, work cited, p. 189; Chavero, Mexico, p. 635, figures a priest burning copal, holding the tlemaitl in the right hand and a bag in the left.

3 Work eited, p. 187; sea shells, cornets, and trumpets were used to sound time. Work cited, p. 189.

- "Chapopoth is a bitumen which resembles the pitch of Castile when it is friable. It is washed up on the beach, usually at high tide and is gathered by the river peoples. It is odorous and is much liked by women. When thrown on the fire its odor spreads widely. It is mixed with the mass which they are in the habit of putting in the adoriferant chalumeaux. They mix tzictli (chicle) with the copal, or incense of the country and with the odorous resin, and they obtain thus good perfume." (Sahagun, p. 630.) See also Torquemada Monarchia, vol. 11, p. 266.

- Bancroft, Native Races, vol. 2, pp. 322-323.
} 
was put in his right hand, and into his left a bag of copal, and thus accoutred and provided, he proceeds to incense the god Huitzilopochtli." 1

In the feast of Tezcatlipoca priests incensed the idol, praying that their prayers might rise to heaven as the smoke of the burning copal. ${ }^{2}$

Incense played an important part in marriage ceremonies, and the contracting parties as well as the household gods were perfumed from the censers. ${ }^{3}$

The Mexicans gave themselves up to a certain superstition to cure sick or sickly infants. They attached to their necks a ball of copal by means of a soft cord of cotton, and they made the same for the wrists and ankles. Astrologers did this under a propitious sign and designated the number of days that they should be borne. They attended to detaching them, and they went at once to burn them all in the capulco. They repeated this four times for each treatment of the child. ${ }^{4}$

Incense was burned to the cardinal points at the feast of the merchants. ${ }^{5}$

In respect to verification the Mexican custom was similar to that of the Iroquois. Sahagiun says:

He touched his hand to the earth and licked the dust that attached to it. He threw then copal on the fire, because that is another way to make oath to say the truth. ${ }^{6}$

Further he says:

The judges did the same before they performed any act of their ministry. Before ceasing their work, they threw copal on the fire to reverence their gods and asked their aicl. The singers of areytos, before commencing to sing, burned likewise copal in honor of their gods and asked their protection. ${ }^{7}$

Thry ofiered morsels of what they had taken to eat to the fire. The custom was called "act of throwing." They also did not drink pulque until a small quantity was placed in a pot near the fire as an offering. Later they threw it out in four different places around the fire.

These Indians reverenced greatly and honored with sacrifices the Gemini, which are fonnd near the Pleiates, in the constellation of the Inull. They employed for that different reremonies at the time when that constellation appeared newly toward the east, after the feast of the sun. They said after they had offered incense: "Yoaltecutli, Yacaniztli is arisen; what will happen this night? Will the influences be prosperous or adverse?" They offered incense three times, without doubt because the constellation is composerl of three stars. These offerings took place at the first hour of night, at 30 'clock in the morning, and at the first glimmer of the dawn. They called these stars "Mamathuazti." If they applied the same word to the sticks which served to produce fire, it is because these Indians found in these sticks of wood some resemblance with the three stars and with what they saw of the origin of the process. There obtained also among the young men the custom of making burns on the wrist in honor of that

\footnotetext{
1 Bancroft, Native Races, vol. 2, p. 145. after Sahagun.

2 Idem, p. 318.

${ }^{3}$ Idem, pp. $250-260$.

- Sahagun, work cited, p. 188.

${ }^{6}$ Bancroft, Native Races, vol. 2, p. 393.

6 Sahagun, work cited, p. 24.

7 Idem, P. $18 \%$.
} 
constellation. They said that one who did not bear these marks at the hour of death would live in hell for the production of fire because they would light it over his wrist by the same process that they employ to produce it by means of morsels of wood. ${ }^{1}$

The Pipiles burned incense at the four corners of a field before weeding. ${ }^{2}$

The Mayas and Mexicans burned incense over the grave of the dead. ${ }^{3}$

A curious instance of substitution in which copal plays a part has been recorded of the Mayas, who during the feast of the month of Mac burnt the hearts of various animals, and if real hearts could not be procured, imitations were formed of copal and sacrificed on the fire. ${ }^{4}$

Another singular custom of the Mayas is referred to by Bancroft:

Respecting their ceremonies before giving battle we only know that on one occasion in Yucatan they brought a brazier of burning perfume which they placed before the Spanish forces, with the intimation that an attack would be made as soon as the fire went out. ${ }^{5}$

2 Bancroft, Native Races, vol. 2, p. 720 .

${ }^{3}$ Idem, p. 799.

Idem, p. 692.

6 Idem, p. 746. 



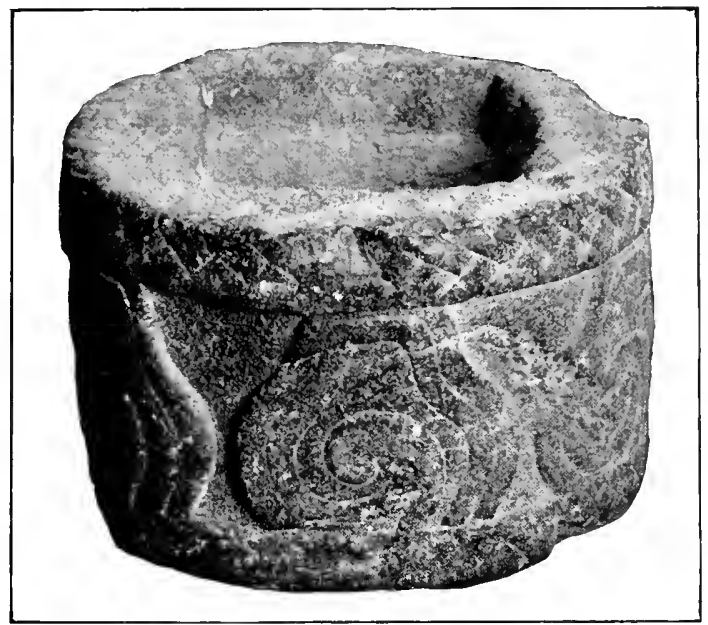

$a$

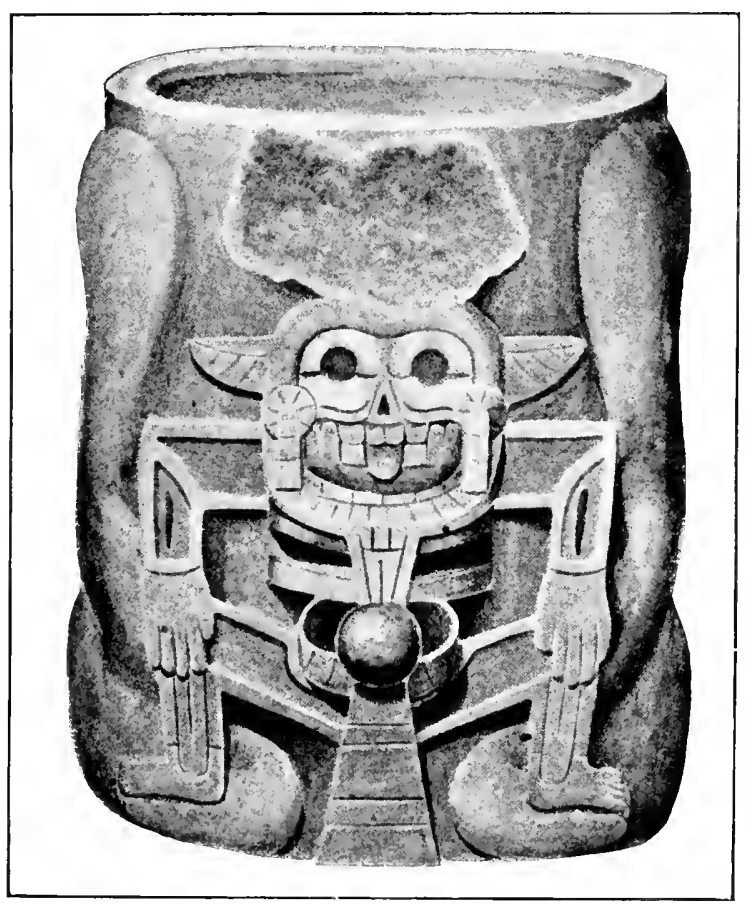

b

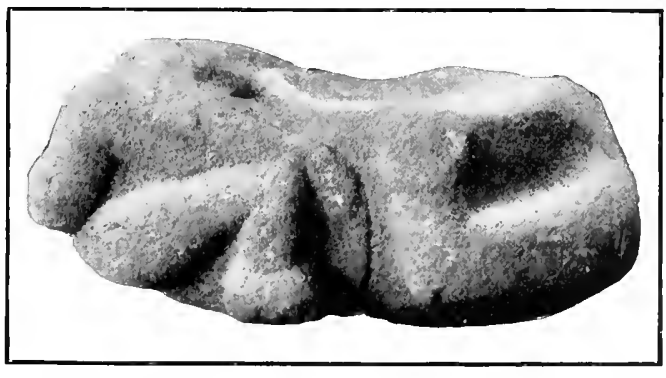

c

Stone Braziers from Mexico and Central america. For descriptions OF FIGURES SEE PAGES 112, 113. 


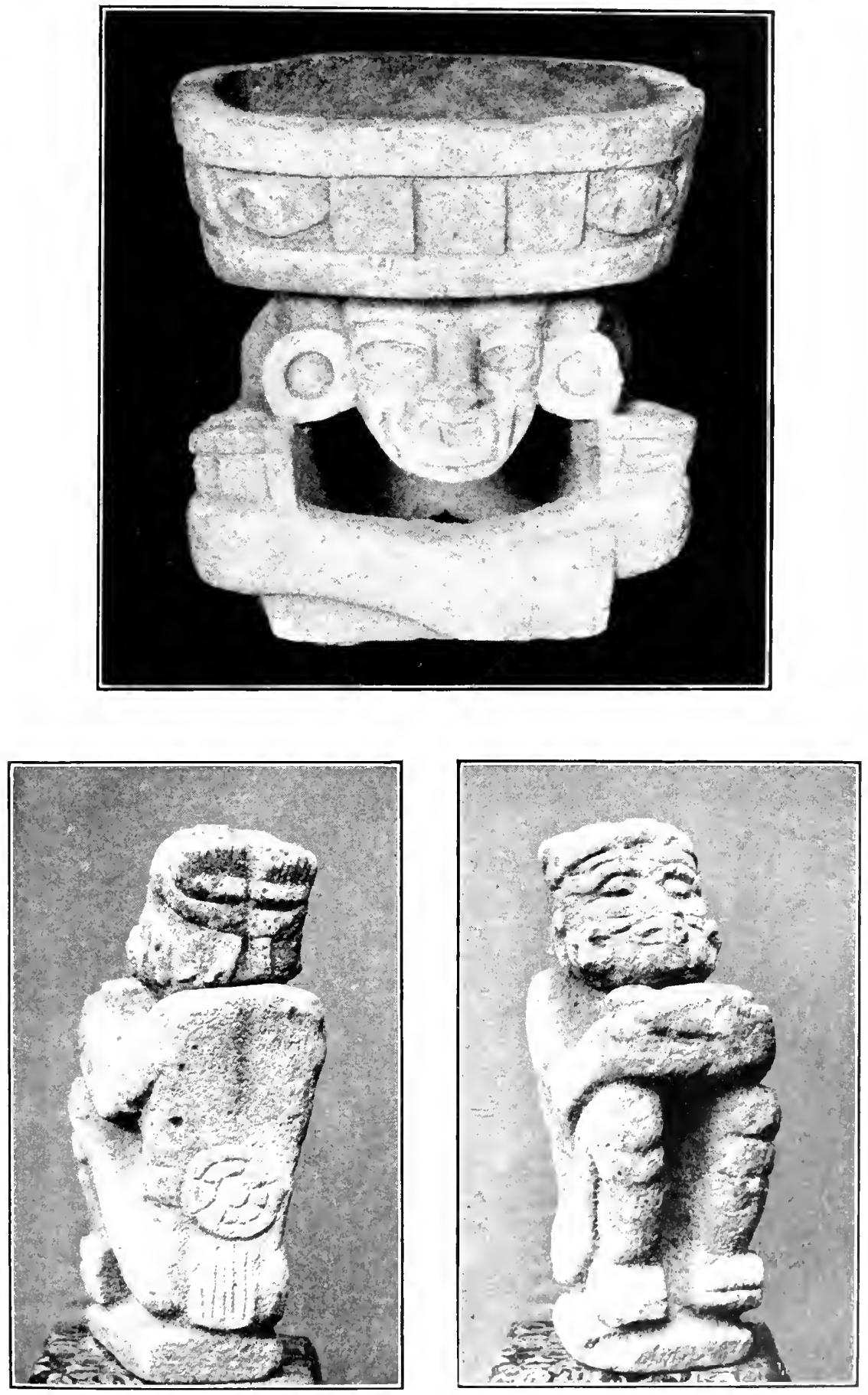

Stone Braziers from Mexico and Central america. 


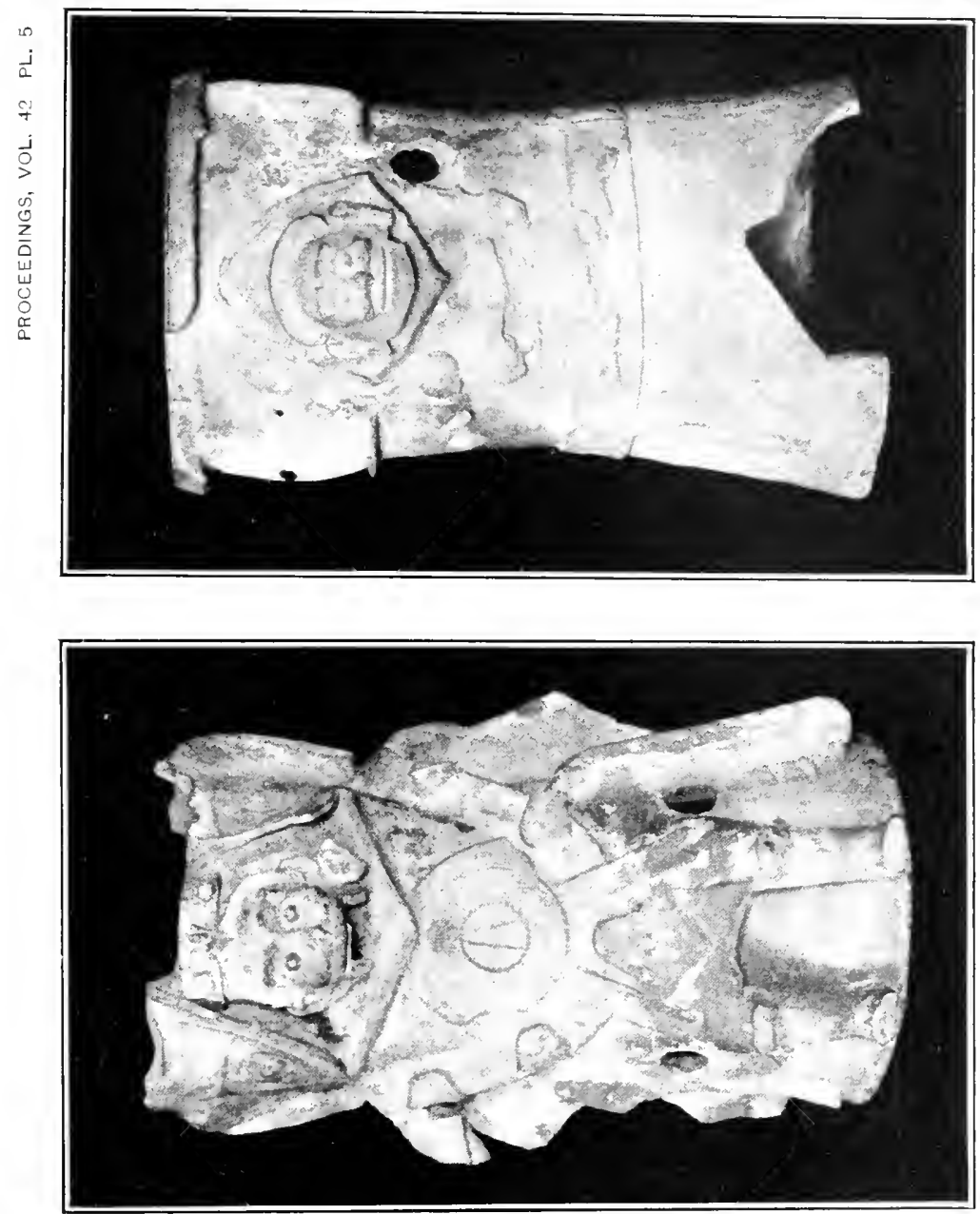

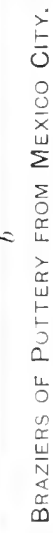

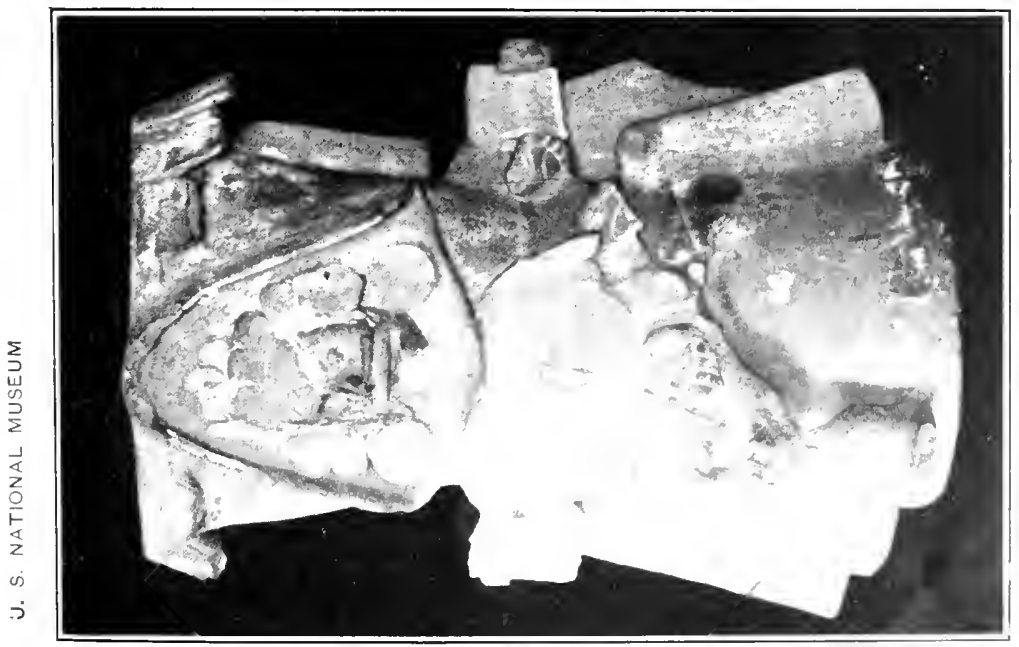




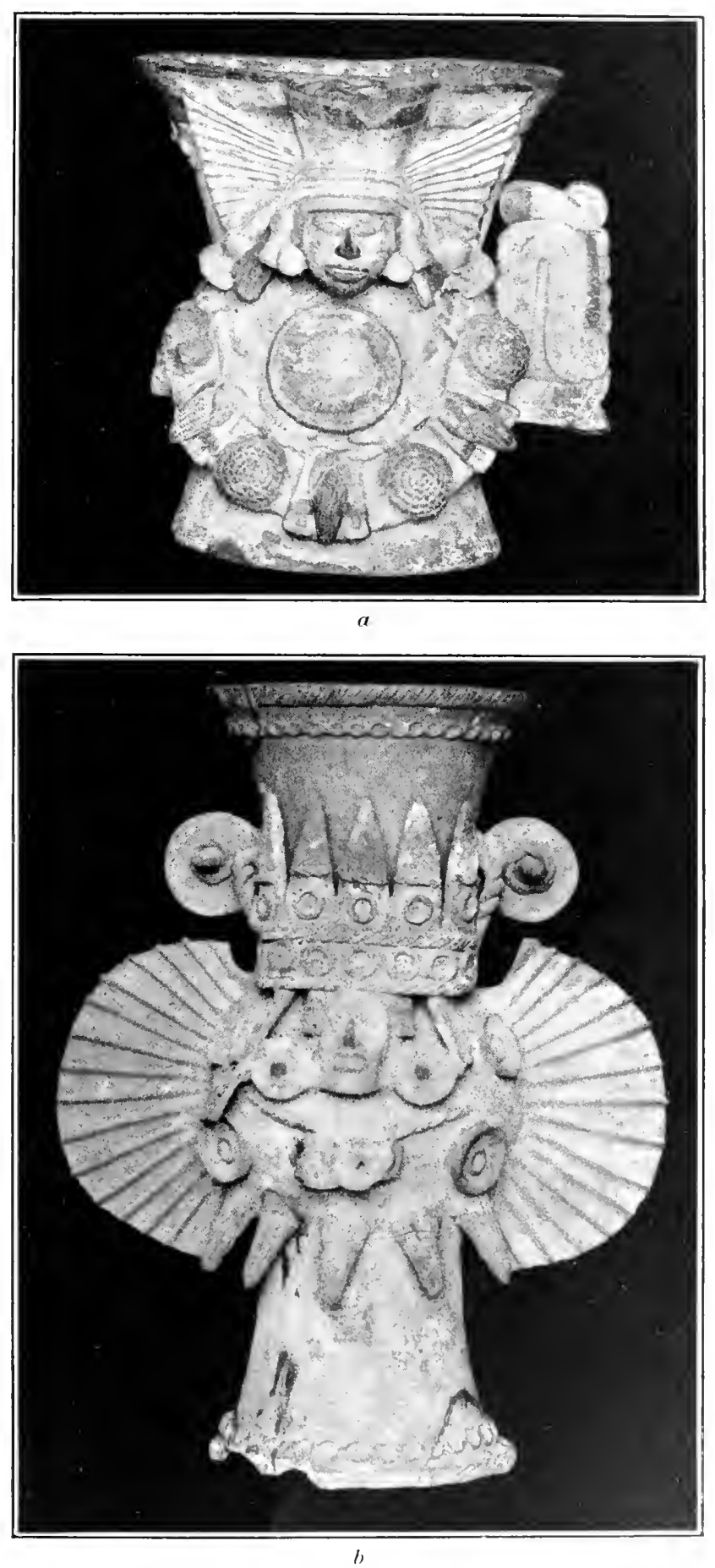

Mortuary VASEs or BRAzIERS from MEXICO. Courtesy of Dr. Nicolas Ltor 



$$
\text { 吕 }
$$





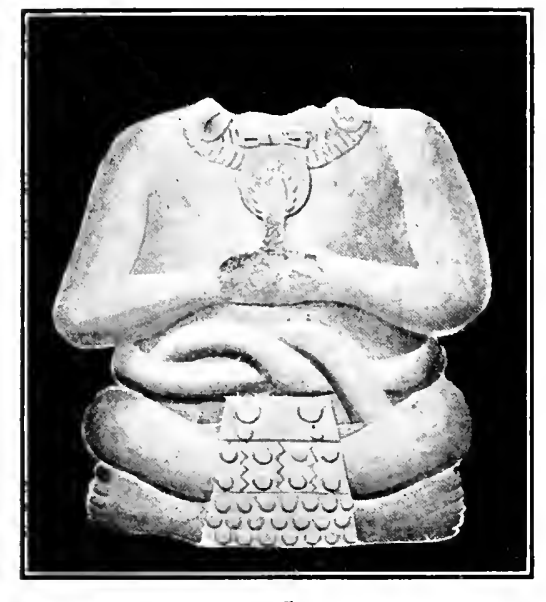

$a$

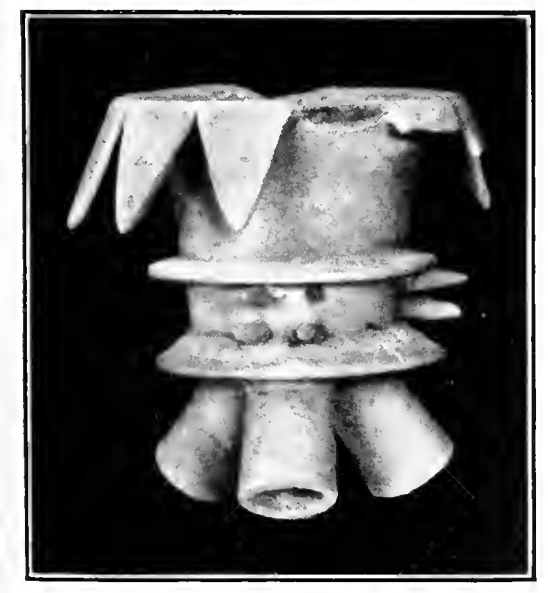

Censers from Mexico and Central america.

FOR DESCRIPTIONS OF FIGURES SEE PAGES $117,119$.
PROCEEDINGS, VOL. 42 PL. 8
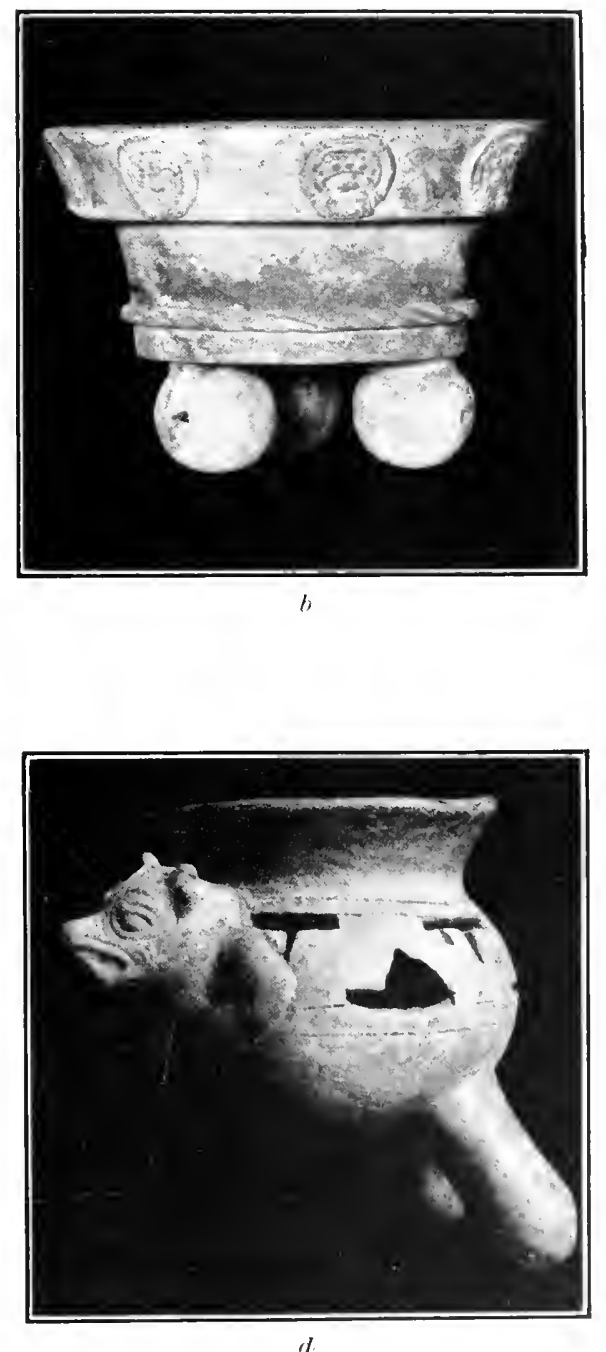



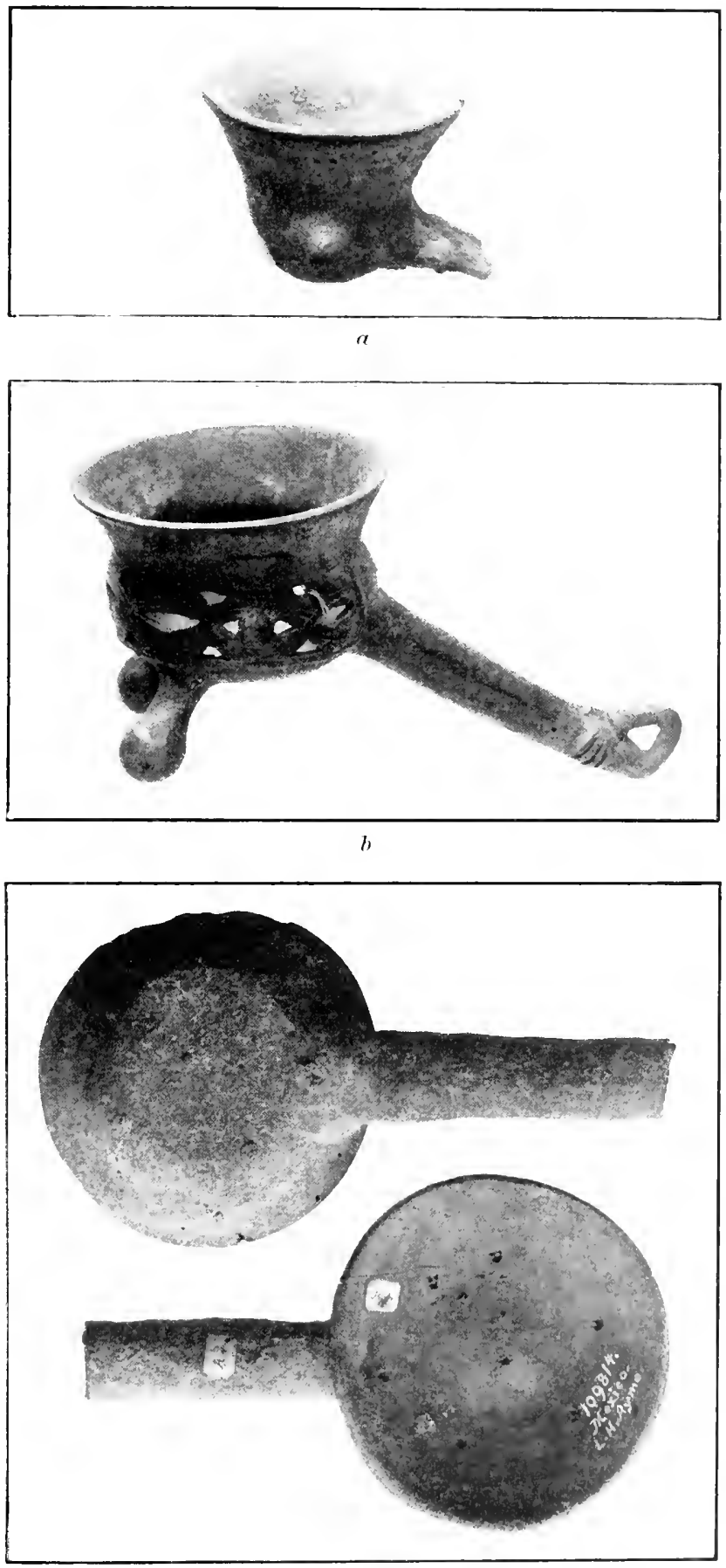

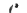

Vase and handle Censers from Mexico.

For descriptions of figures See pages $121,122$. 



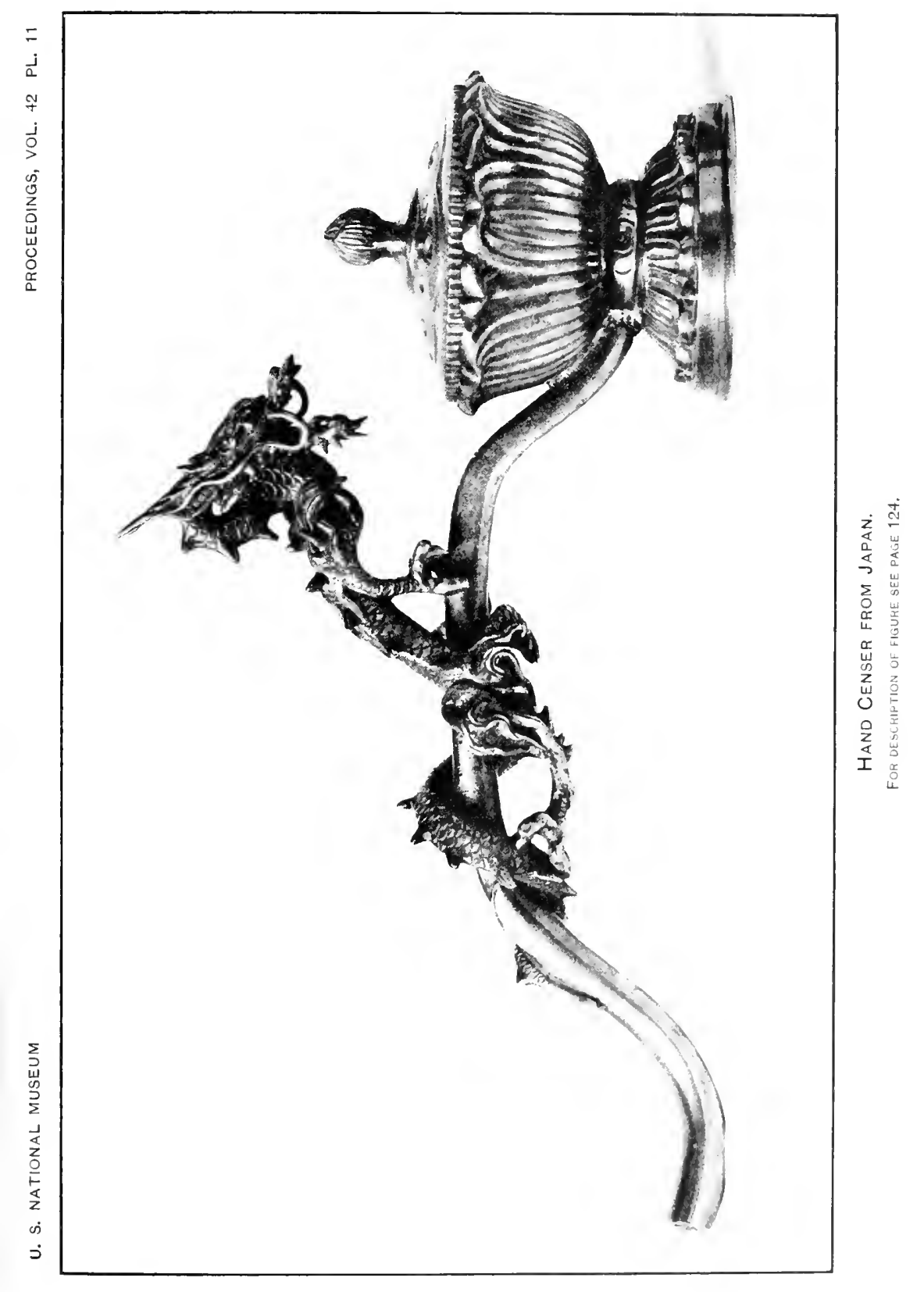




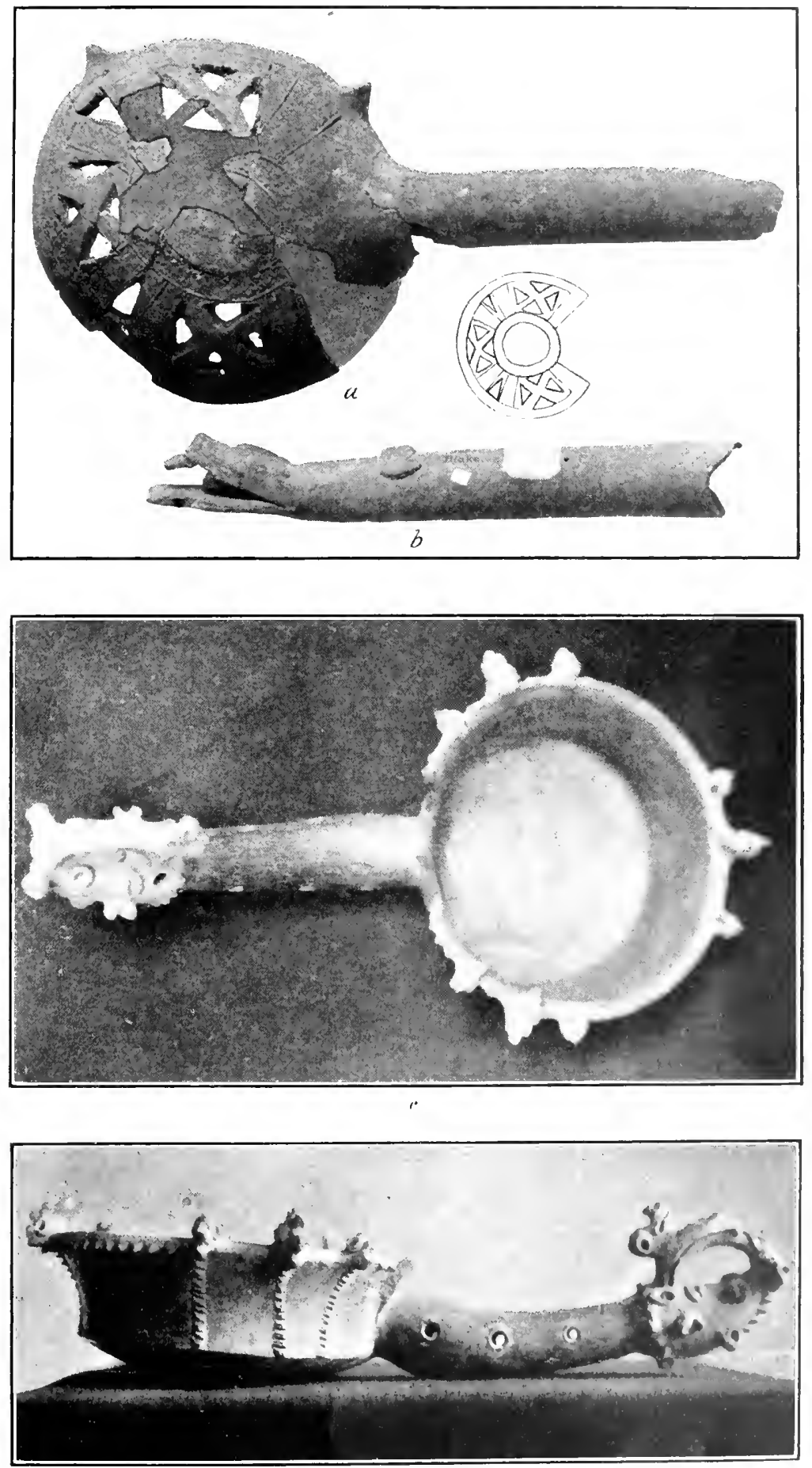

Handle. Censers from Mexico and Central america.

For DESCRiptions OF FIGURES SEE PAGES $122,124$. 



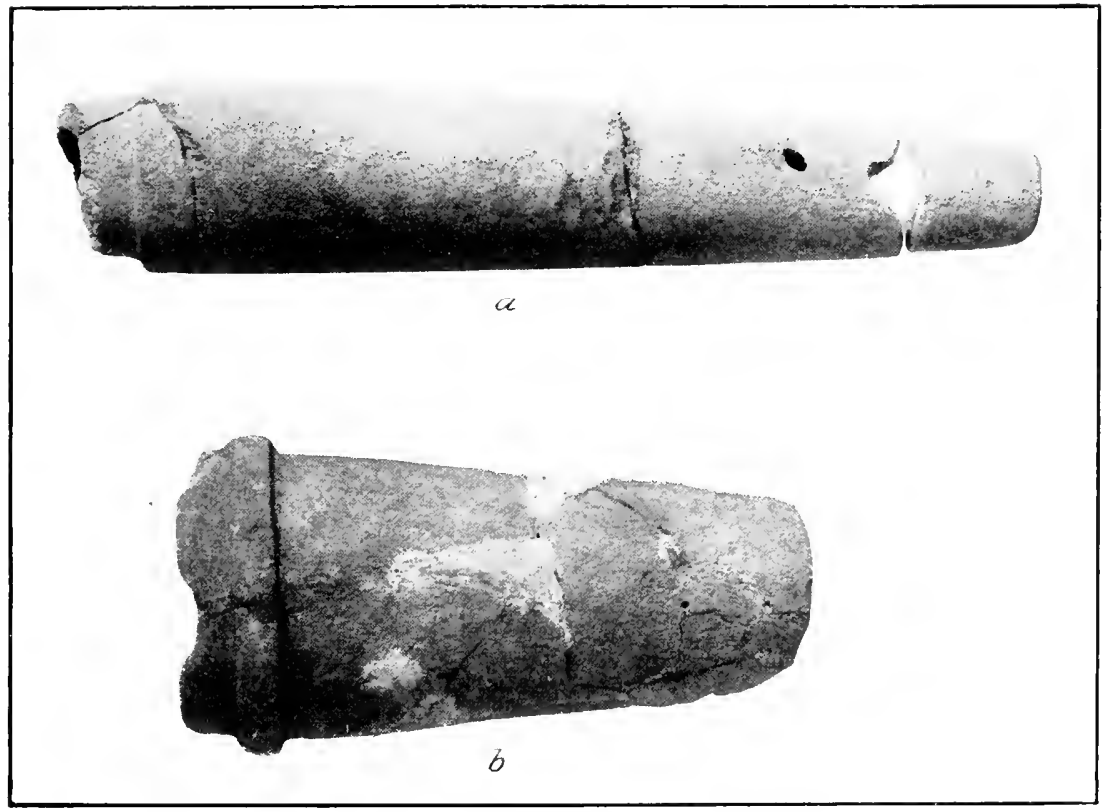

InCENSE TUBES from NeW MeXico.

For DESCRIPTIONS OF FIGURES SEE PAGE 126. 



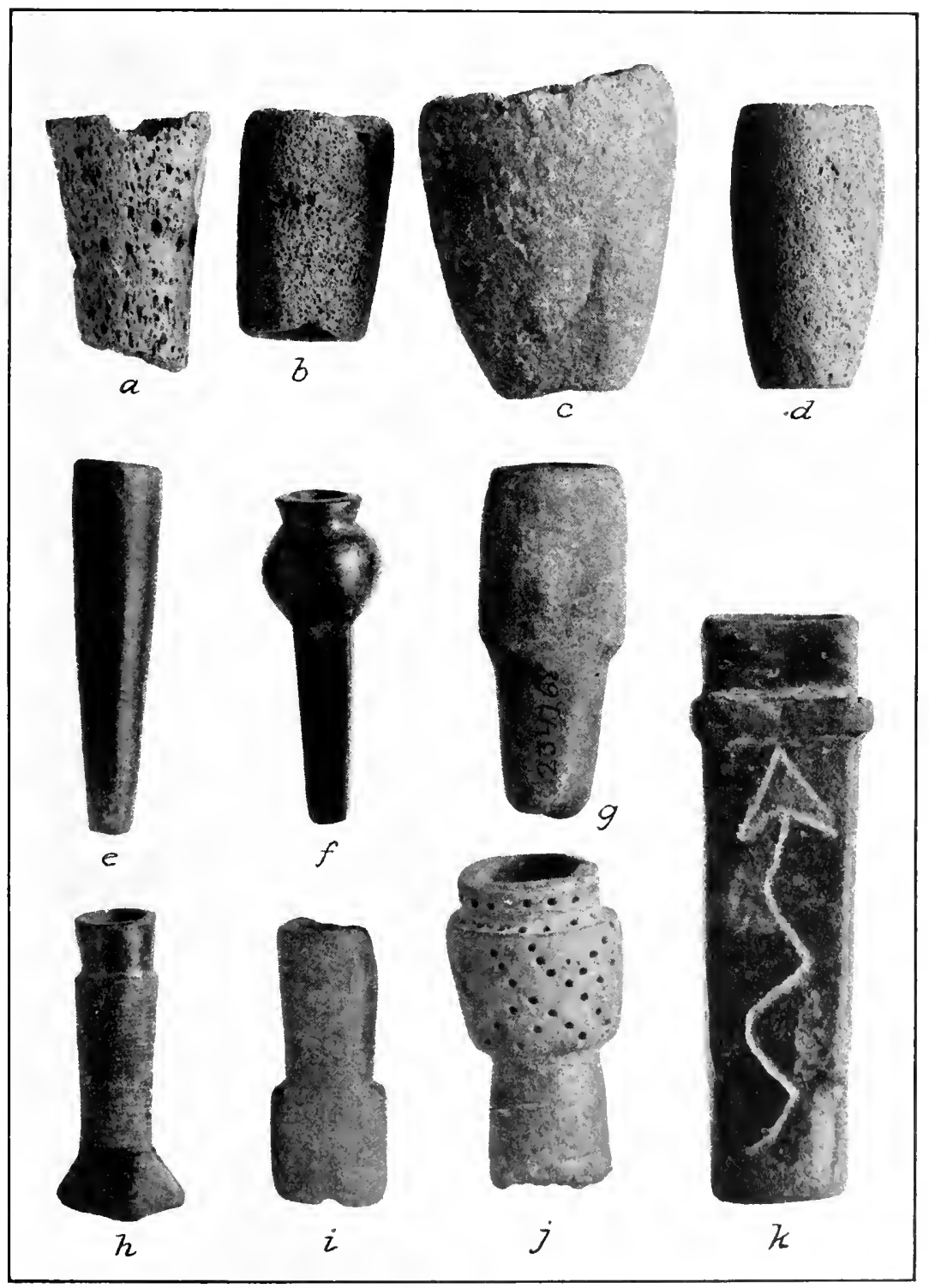

Tubular Pipes from arizona and New Mexico.

For descriptions of FIGURES SEE PAGES 127, 128, AND 129. 




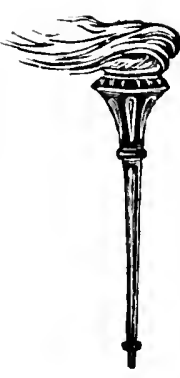

